\title{
Structure and Development of Two Merged Rainbands Observed over the East China Sea during X-BAIU-99 Part II: Meso- $a$-Scale Structure and Build-up Processes of Convergence in the Baiu Frontal Region
}

\author{
Qoosaku MOTEKI, Hiroshi UYEDA, Takeshi MAESAKA, Taro SHINODA \\ Hydrospheric Atmospheric Research Center, Nagoya University, Nagoya, Japan \\ Masanori YOSHIZAKI and Teruyuki KATO \\ Meteorological Research Institute, Tsukuba, Japan
}

(Manuscript received on 6 March 2002, in final form on 12 September 2003)

\begin{abstract}
In this paper, the synoptic- and meso- $\alpha$ scales structure of two oceanic rainbands, and build-up processes of the frontal convergence, are investigated with the use of a regional spectral model (RSM) and a nonhydrostatic model (NHM). Over the eastern part of the East China Sea on 27 June 1999 during the X-BAIU-99, we observed that a northern rainband (LINE2) merged into a southern rainband (LINE1), and LINE1 developed rapidly. Before their merging, LINE1 and LINE2 developed along the "water vapor front" and the Baiu front, respectively. The "water vapor front," found by the meso- $\beta$-scale analyses of Part I of this series, is a weak convergence line with a large moisture gradient in a southerly wind field. In the RSM-simulated field, the "water vapor front" extended from the eastern coast of China with a length of about $1000 \mathrm{~km}$. The NHM simulation revealed that the "water vapor front" is a convergence line with oceanic southwesterly and continental westerly flows. The convergence line formed a meso- $\alpha-$ scale rainband (LINE1) in the southerly wind field over the ocean without any land effects. Because an abundant moisture supply with the oceanic airflow was blocked at the "water vapor front" by the continental airflow, the rainfall intensity was quite weak along the western part of the Baiu front. The lowlevel convergence of the eastern part of the "water vapor front" was quite weak, the oceanic air had partially advected into the eastern part of the Baiu front, and LINE2 developed strongly. In a synoptic-scale cold air mass to the north of the Baiu front, a meso- $\alpha$-scale cold pool formed in a stratiform precipitation region. The cold pool expanded to the south, and pushed rapidly southward the Baiu front, about $50 \mathrm{~km}$ in 2 hours. It was confirmed that the cold pool was created by an evaporation cooling of raindrops from a sensitivity experiment. The experiment revealed that the cold pool continuously accelerated northerly winds, and intensified the low-level convergence along the Baiu front. In the areas of the southern side of the Baiu front, and the "water vapor front," southerly winds were greatly accelerated over $5 \mathrm{~m} \mathrm{~s}^{-1}$ in 4 hours by the pressure gradient force enhanced near the convective rainfalls of LINE1 and LINE2. The frontal convergence along both fronts were greatly enhanced by the acceleration of the southerly winds.
\end{abstract}

Corresponding author: Qoosaku Moteki, Hydrospheric Atmospheric Research Center, Nagoya University, Nagoya 464-8601, Japan.

E-mail: moteki@rain.hyarc.nagoya-u.ac.jp

(C) 2004, Meteorological Society of Japan

\section{Introduction}

The Baiu front has some features that are different from those of typical midlatitude fronts. Compared to warm and cold fronts associated with extratropical cyclones, it is well 
known that the Baiu front is characterized by a weak temperature contrast, but is accompanied by a large moisture contrast (Akiyama 1973; Ninomiya 1984). Generally, the Baiu frontal structure is very shallow, and the Baiu frontal surface slopes gently with height (Ding 1992). A low-level cyclonic wind-shear line is located $200-300 \mathrm{~km}$ north of the position of the Baiu front at the surface (Chen et al. 1998). In these synoptic-scale features, it is well recognized that there is a hierarchy of disturbances in the Baiu frontal region: synoptic-scale, meso$\alpha$-scale, meso- $\beta$-scale, and meso- $\gamma$-scale (Ninomiya and Akiyama 1992). Although they schematically present the multiscale features of horizontal rainfall distributions in the Baiu frontal region, three-dimensional mesoscale structure of a Baiu frontal precipitation system has not been sufficiently revealed. Multiscale analyses using various data are needed for understanding precipitation phenomena in the Baiu frontal region.

In order to study the Baiu frontal precipitation systems, a field experiment of X-BAIU-99 (" $X$ " is an abbreviation for the East China Sea: ECS and indicates a mystery as well.) was performed during the 1999 Baiu season (Yoshizaki et al. 2000). Sufficient multiscale data (upperair sounding, C-band radars, X-band Doppler radars, and surface meteorological observations) were obtained during this experiment. On 27 June 1999 during the X-BAIU-99, two oceanic rainbands were observed in the Baiu frontal region of the typical synoptic-scale features, as shown in Part I of this series (Moteki et al. 2003). The meso- $\beta$-scale structure and development processes of the rainbands were investigated by dual Doppler analysis. A northern rainband (LINE2), which formed along the Baiu front, moved rapidly southward in association with the southward propagation of the Baiu front. Because a southern rainband (LINE1) was quasi-stationary, LINE2 merged with LINE1. As the merging occurred, LINE1 developed rapidly over the eastern part of the East China Sea.

Those observed features of the rainbands were well reproduced by a $5-\mathrm{km}$ resolution nonhydrostatic model (5 km-NHM). According to the numerical study in Part I, a weak convergence line, with a large moisture gradient, is found in the south of the Baiu front. The con- vergence line is named a "water vapor front." LINE1 formed along the "water vapor front" over the ocean without any land effects (upslope flow and surface heating over the mountains or the barrier jet along a coast, for example.). Because the length of LINE1 along the "water vapor front" was over $150 \mathrm{~km}$, meso- $\alpha$ scale analyses were also required to understand the behavior and three-dimensional structure of the "water vapor front." In addition, the cause of the southward propagation of the Baiu front is needed to be clarified because the merging of the two rainbands resulted from that propagation of the Baiu front. For clarifying the cause of the propagation, it is necessary to investigate the thermodynamic and moisture fields around the Baiu front.

The meso- $\beta$-scale analyses in Part I also showed that LINE1 developed rapidly in the merging process as a result of an intensification of low-level convergence. The intensification of the convergence was caused by a northerly outbreak associated with the Baiu front. However, the build-up processes of the frontal convergence before the merging still is needed to be clarified. Although a synoptic-scale convergence with the Baiu front is generally weak, several previous studies have shown that two mesoscale processes intensify the convergence. One is associated with the development of a mesoscale cold pool, and the other is a process of decreased pressure, which is induced by diabatic heating.

The process associated with a mesoscale cold pool is often observed as the formation of a gust front. Because the mesoscale cold pool is created by an evaporation of precipitation particles, it is generally recognized that a mesoscale cold pool is rarely observed in the Baiu frontal region in which the lower layer is very moist. However, in the late period of the Baiu season, the development of the Baiu frontal precipitation system with a mesoscale cold pool has been occasionally observed. Ishihara et al. (1995) showed that a Baiu frontal rainband was maintained for 7 hours by a self-maintaining mechanism with the formation of the cold pool. In a numerical study, Nagata and Ogura (1991) demonstrated that the cold pool formed in a stratiform precipitation region, and had a local effect on enhancing the front genesis along the Baiu front. 
The process of decreased pressure is often discussed in the numerical studies of a lowlevel jet. Nagata and Ogura (1991) and Kato (1998) showed that the process of decreased pressure strengthened the weak convergence along the Baiu front. As a remarkable decrease of pressure is induced in the convective rainfall, moist southerly winds are accelerated by the enhanced pressure gradient force. The moist southerly winds increase the water vapor flux into a precipitation system, and the convective rainfall develops more and more intensely for a long time. It is recognized that there was a positive feedback between the intensification of a precipitation system and the acceleration of southerly winds (Chen et al. 1998).

The two mesoscale processes could have significant roles for the intensification of the convergence along the Baiu front and the "water vapor front" on 27 June 1999. Because the rainbands along the two fronts formed in the late period of the Baiu season and had a stratiform precipitation region, the formation of a mesoscale cold pool should be confirmed. Its effects on the frontal motion, and frontal convergence, were needed to be investigated. The process of decreased pressure is considered to be strongly affected with a moisture supply from the south. A huge amount of water vapor near a precipitation system is required for driving this process as a source of energy. It is necessary to investigate the relation between the process and a distribution of water vapor in a lower layer.

The first objective of this paper is to present three-dimensional thermodynamic and moisture structures around the two fronts by using a regional spectral model (RSM) and the $5 \mathrm{~km}$ NHM. The second objective is to investigate the build-up processes of convergence along the two fronts. Finally, according to the multiscale analyses in this two-part series, we will discuss the multiscale structures of the Baiu frontal region including the two fronts and the two rainbands. Section 2 describes the two models used in this study and an experimental design. In Section 3, synoptic-scale features of thermodynamic and moisture fields in the Baiu frontal region are described by using the RSM simulation. The behaviors and three-dimensional structures of the two fronts are examined by using the $5 \mathrm{~km}-\mathrm{NHM}$ simulation in Section

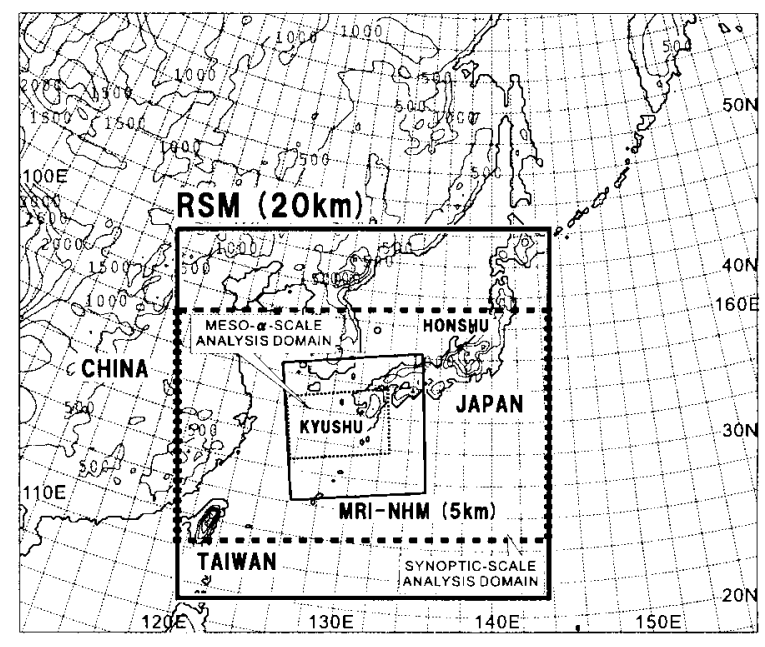

Fig. 1. Domains of a $20-\mathrm{km}$ resolution hydrostatic model: RSM (the thicklined box) and a 5-km resolution nonhydrostatic model: $5 \mathrm{~km}-\mathrm{NHM}$ (the thin-lined box). Analysis domains of synoptic-scale and meso- $\alpha$-scale are represented by the thick and thin dotted boxes, respectively.

4. Section 5 presents the build-up processes of convergence along the two fronts before the frontal merging. Conceptual models of synoptic, meso- $\alpha$, and meso- $\beta$ scales structures of the rainbands with comparisons to the traditional models are presented in Section 6 .

\section{Model description}

In this study, the outputs of RSM and $5 \mathrm{~km}-$ NHM are used to analyze synoptic-scale and meso- $\alpha$-scale fields, respectively (Fig. 1). The RSM is a hydrostatic model which is operationally used in Japan (Segami et al. 1989). The horizontal resolution is about $20 \mathrm{~km}$. The RSM has $129 \times 129$ grid points (in the thick-lined box) and 36 vertical $\sigma$-levels. The RSM was integrated for 24 hours from 21 JST on 26 June 1999, and its output was used for synoptic-scale analyses (in the thick-dotted box). Upper-air sounding data at seven additional sites (Nagashima, Shimokoshiki, and Minamitane, and observation vessels Seifu Maru, Chofu Maru, Keifu Maru, and Shumpu Maru; see Fig. 1 in Part I of this series) during the X-BAIU-99, were included in the initial field of the RSM. A nonhydrostatic model, which was developed by 
the Meteorological Research Institute in Japan (Saito et al. 2001), is used with a horizontal grid size of $5 \mathrm{~km}$ and $200 \times 200$ grid points (in the thin-lined box) for meso- $\alpha$-scale analyses (in the thin-dotted box). The vertical grid contains 38 levels with variable grid intervals ( $\Delta z=20 \mathrm{~m}$ near the surface and $\Delta z=1060 \mathrm{~m}$ at the top level). The same experimental design as for Part I is used in this study. The precipitation physics of mixed-phase processes, predicting the mixing ratios of rainwater, cloud water, cloud ice, snow and graupel, is used. A time step of $\Delta t=10$ seconds is used. The $5 \mathrm{~km}$ resolution nonhydrostatic model (5 km-NHM) was one-way-nested within the RSM with an integration time of 9 hours from 06 JST on 27 June 1999. The lateral boundary data, which was provided from the RSM, was given every 3 hours.

\section{Synoptic-scale structure of the Baiu frontal region}

According to the synoptic overview in Part I based on the weather map at 09 JST on 27 June 1999 (Fig. 2a), typical features in the late period of the Baiu season were seen as follows. The Baiu front extending from the west to the east was quasi-stationary and had a larger baroclinicity to the east from $125^{\circ} \mathrm{E}$. A midlevel humid region (surrounded by a dashed line), called "moist tongue," extended from China to the western sea of Kyushu. Because there was a "water vapor front" in the south of the Baiu front, as shown by the meso- $\beta$-scale analyses in Part I, the synoptic-scale analysis in this section focused on the southern side of the Baiu front.

The simulated fields of rainfall, potential temperature $\theta$ and mixing ratio of water vapor $q_{v}$ with the RSM at 09 JST on 27 June ( $t=$ $12 \mathrm{hr}$ ) were used to investigate the synopticscale structures of the Baiu frontal region (Figs. $2 \mathrm{~b}, 2 \mathrm{c}$, and $2 \mathrm{~d}$ ). The simulated fields with the RSM were quite consistent with the observations as follows. The Baiu front in the RSM simulation is defined by considering a synoptic convergence of northerly and southerly winds, and gradients of $\theta$ and $q_{v}$ at the surface. The orientation and horizontal extension of the simulated Baiu front are consistent with the surface weather map, except that its position is slightly shifted to the south. Over the East
China Sea, the $\theta$ gradient across the Baiu front is weak (less than $2 \mathrm{~K}$ per $100 \mathrm{~km}$ ), but becomes a little larger to the east (Fig. 2b). The simulated Baiu front is accompanied by a remarkable $q_{v}$ gradient of $2 \mathrm{~g} \mathrm{~kg}^{-1}$ per $100 \mathrm{~km}$ from $15 \mathrm{~g} \mathrm{~kg}^{-1}$ to $17 \mathrm{~g} \mathrm{~kg}^{-1}$ (Fig. 2c). At 700 $\mathrm{hPa}$, a high $q_{v}$ area over $8.5 \mathrm{~g} \mathrm{~kg}^{-1}$, corresponding with the "moist tongue," extends from the China continent to Kyushu (Fig. 2d). The horizontal distribution and position of the simulated "moist tongue" are also consistent with the observed one. Two main areas of rainfall around a weak cyclone $\left(37^{\circ} \mathrm{N}, 135^{\circ} \mathrm{E}\right)$, and over the East China Sea, are well reproduced in comparison with the infrared image with the Geostationary Meteorological Satellite (GMS).

Over the East China Sea at the surface, a remarkable $q_{v}$ gradient $\left(2 \mathrm{~g} \mathrm{~kg}^{-1}\right.$ per $100 \mathrm{~km}$ from $17 \mathrm{~g} \mathrm{~kg}^{-1}$ to $19 \mathrm{~g} \mathrm{~kg}^{-1}$ ) distinct from the Baiu front, is found in a southerly wind field (Fig. 2c). This $q_{v}$ gradient is accompanied by a weak convergence and a weak rainfall (marked as WVFR). Considering the results of the meso$\beta$-scale analyses in Part I, the $q_{v}$ gradient with a weak convergence could be associated with the "water vapor front" (indicated by the dashed line). The "water vapor front" is seen to extend from the eastern coast of China (near $25^{\circ} \mathrm{N}$ ) with a length of about $1000 \mathrm{~km}$. The "water vapor front" can be regarded as the northern edge of an oceanic high $q_{v}$ air $\left(>19 \mathrm{~g} \mathrm{~kg}^{-1}\right)$, which differs from a continental one (higher $\theta$ but smaller $q_{v}$ of less than $17 \mathrm{~g} \mathrm{~kg}^{-1}$ ). Along the western edge of the subtropical Pacific high, this oceanic moist air flows into the Baiu frontal region of the eastern part of the East China Sea $\left(125 \sim 130^{\circ} \mathrm{E}\right)$. At $700 \mathrm{hPa}$, a cyclonic windshear line (indicated by the open symbol of a stationary front) is located $150-200 \mathrm{~km}$ north of the Baiu front at the surface to the west from $130^{\circ} \mathrm{E}$ (Fig. 2d). This position of the cyclonic wind-shear line at $700 \mathrm{hPa}$ suggests that a synoptic-scale cold air mass is very shallow over the East China Sea.

A schematic diagram of a synoptic-scale structure of the Baiu frontal region is presented in Fig. 3. The Baiu front, and the "moist tongue," extends from China to Kyushu in a west-east direction. The Baiu frontal structure could be very shallow over the East China Sea, as suggested by the position of the cyclonic wind-shear line at $700 \mathrm{hPa}$. Although an in- 

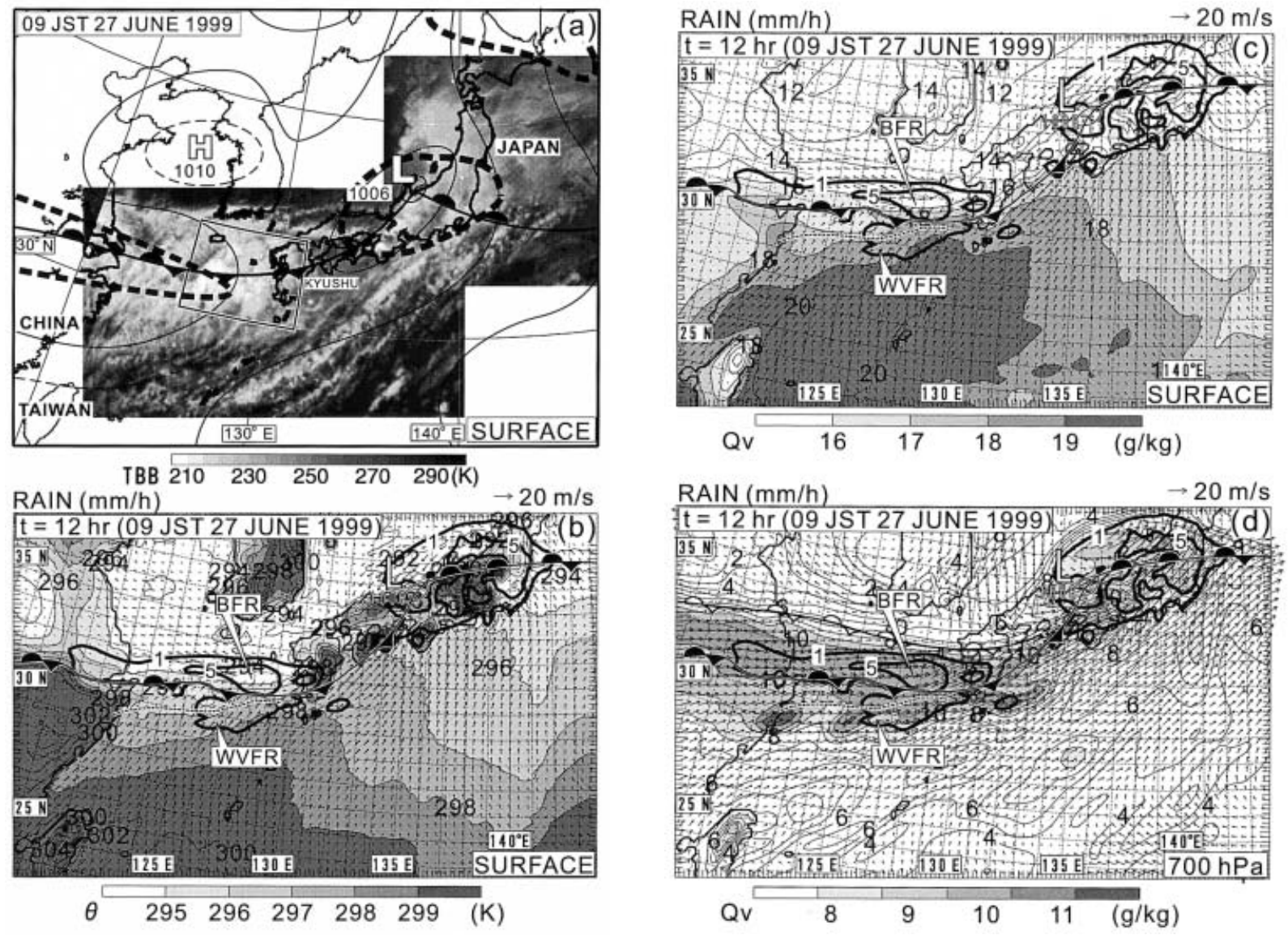

Fig. 2. (a) Surface weather map at 09 JST on 27 June 1999 . The wet area $\left(\mathrm{T}-\mathrm{Td}<3^{\circ} \mathrm{C}\right)$ at $700 \mathrm{hPa}$ surrounded by the dashed line and the GMS infrared image around the Baiu front are superimposed. A box is a domain of a composite reflectivity image with three C-band radars. (b) Potential temperature at the surface (contoured every $1 \mathrm{~K}$ and shaded over $295 \mathrm{~K}$ ), (c) mixing ratio of water vapor at the surface (contoured every $1 \mathrm{~g} \mathrm{~kg}^{-1}$ and shaded over $16 \mathrm{~g} \mathrm{~kg}^{-1}$ ) and (d) the same as (c) except at $700 \mathrm{hPa}$ (contoured every $1 \mathrm{~g} \mathrm{~kg}^{-1}$ and shaded over $8 \mathrm{~g} \mathrm{~kg}^{-1}$ ) at $t=12 \mathrm{hr}$ (valid at 09 JST 27 June 1999) reproduced by the RSM. Rainfall areas of 1 and $5 \mathrm{~mm} \mathrm{~h}^{-1}$ are indicated by thick contours. The position of the "water vapor front" is indicated by dashed line in (b), (c) and (d). Rainfall areas associated with the Baiu front and the "water vapor front" are marked as BFR and WVFR, respectively.

homogeneousness of moisture supply from the south rarely received attention in previous synoptic-scale analyses, the analyses using the RSM-simulated field described the significant features in the surface $q_{v}$ distribution as follows. The eastern part of the East China Sea is the most humid region compared to the other parts in the south of the Baiu front (e.g., over the continent and the western part of the East China Sea). The "water vapor front" can be regarded as a remarkable $q_{v}$ gradient between the oceanic (quite moist) and continental (rela- tively dry) air masses. The "water vapor front" with the $q_{v}$ gradient extends from the eastern coast of China with a length of about $1000 \mathrm{~km}$.

\section{Meso- $a$-scale structure of two fronts}

From the analysis of the synoptic-scale field, the eastern part of the East China Sea was found to be a quite favorable region for securing a large moisture supply from the south. Threedimensional meso- $\alpha$-scale analyses over this region are required for understanding the merging process of the Baiu front and the "water 


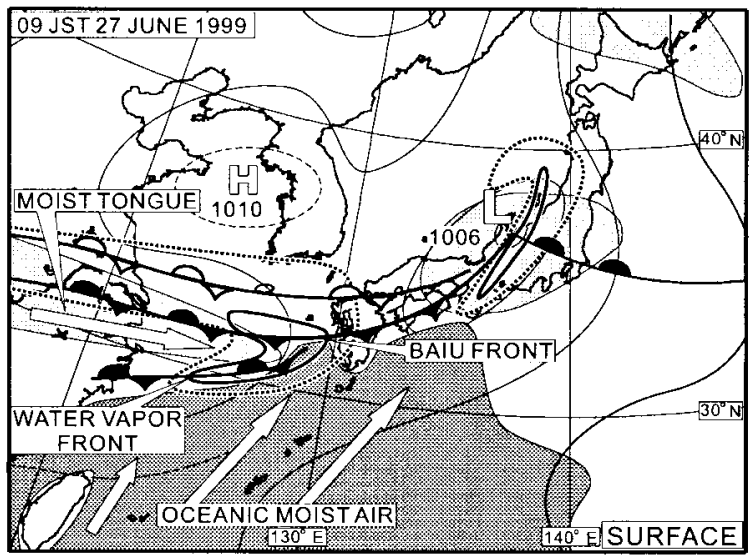

Fig. 3. Schematic diagram of synopticscale structure of the Baiu frontal region based on the surface weather map at 09 JST 27 June 1999. The dark and light shaded areas indicate distributions of the oceanic moist air at the surface and the moist tongue at $700 \mathrm{hPa}$, respectively. Areas of weak and convective rainfall are surrounded by dotted and solid lines, respectively. The symbol of a stationary front in the south of the Baiu front over the East China Sea denotes the "water vapor front." The open symbol of a stationary front to the north of the Baiu front indicates the cyclonic wind-shear line at $700 \mathrm{hPa}$.

vapor front." In this section, the meso- $\alpha$-scale behaviors of the two fronts is described by using C-band radar data and the $5 \mathrm{~km}-\mathrm{NHM}$ simulation.

In order to investigate the meso- $\alpha$-scale behaviors of the two precipitation bands associated with the two fronts from observational data, horizontal reflectivity fields of three Cband radars $(r=250 \mathrm{~km})$ at Fukuoka, Tanegashima and from the Keifu Maru were composited (Fig. 4). From the meso- $\beta$-scale analyses in Part I of this series, it was confirmed that precipitation bands* in the southern side (BAND1) and northern side (BAND2) were associated with the "water vapor front" and the Baiu front,

* A band of precipitation echoes was determined in the same way as in Part I. Band-shaped precipitation echo area with C-band radar is called "BAND" in this study.

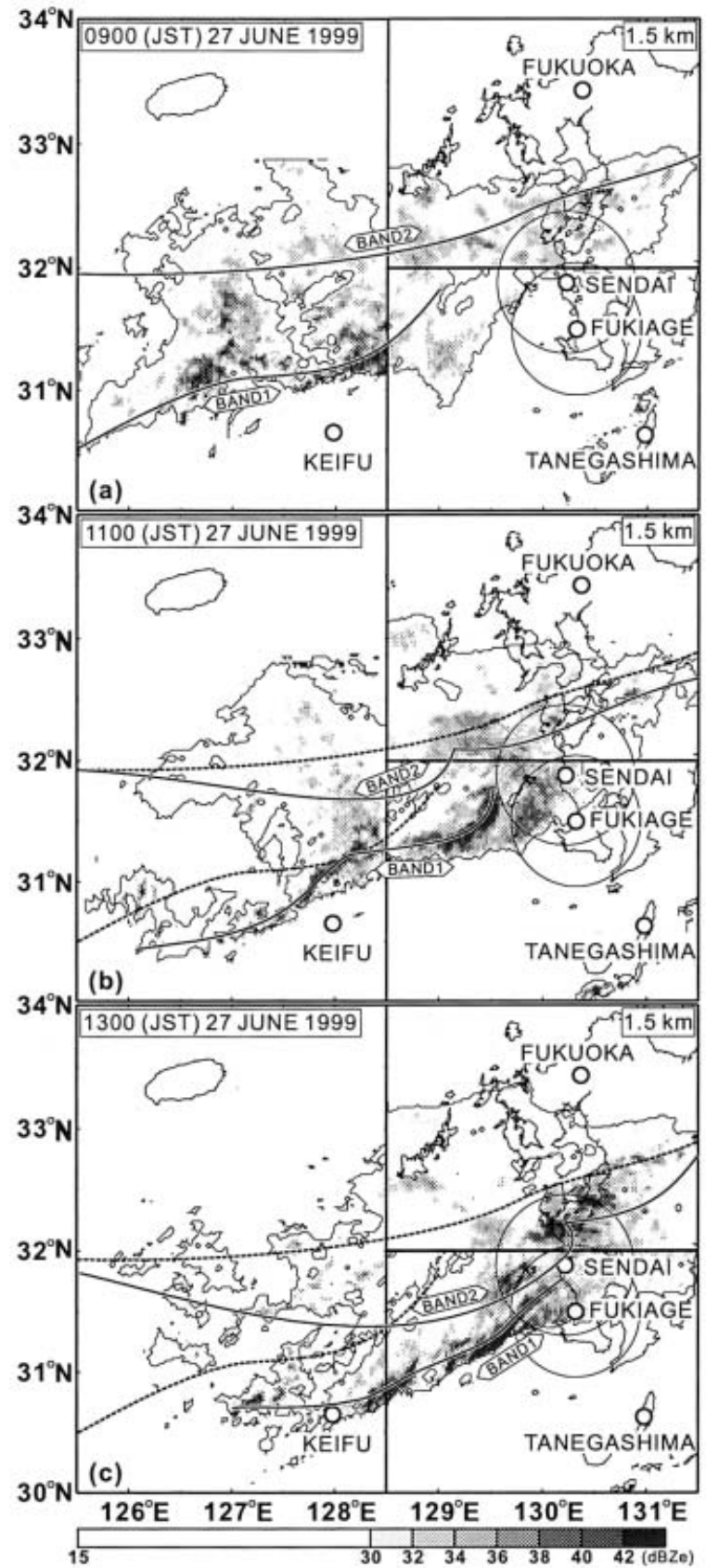

Fig. 4. Horizontal reflectivity fields of composite images with three C-band radars at (a) $0900 \mathrm{JST}$, (b) $1100 \mathrm{JST}$ and (c) 1300 JST. The echo areas are bordered with boundaries of $15 \mathrm{dBZe}$. The composite area is indicated by the box in Fig. 2(a). The positions of BAND1 and BAND2 are indicated by the solid lines. The dashed lines shown in (b) and (c) represent the positions of BAND1 and BAND2 at 0900 JST. 
respectively. At 0900 JST, BAND2 was located near $32^{\circ} \mathrm{N}$ with a west-east orientation and BAND1 was located about $100 \mathrm{~km}$ south of BAND2. The maximum lengths of BAND1 and BAND2 were about 350 and $600 \mathrm{~km}$, respectively. BAND1 was quasi-stationary in the north-south direction till 1300 JST. On the other hand, a remarkable southward motion of BAND2 (more than $50 \mathrm{~km}$ per 4 hours) occurred between $127^{\circ} \mathrm{E}$ and $130^{\circ} \mathrm{E}$, and BAND2 merged into the northeastern part of BAND1 at $1300 \mathrm{JST}$. In the north of BAND2 during the 4 hours from 0900 JST, a broad weak echo $(<30 \mathrm{dBZe})$ of the stratiform precipitation region was observed to expand to the north. After their merging, BAND1 moved southward at the same speed of BAND2 till about 1500 JST (not shown).

To examine the meso- $\alpha$-scale structures of airflow, thermodynamic and moisture around the two fronts and their behaviors, simulated results with the $5 \mathrm{~km}-\mathrm{NHM}$ are used. The $5 \mathrm{~km}-\mathrm{NHM}$ simulation was well verified with the meso- $\beta$-scale analyses of observational data in Part I as follows. In comparison with the actual observations with $\mathrm{C}$-band radars and $\mathrm{X}$ band Doppler radars, the $5 \mathrm{~km}-\mathrm{NHM}$ was well reproduced structure and merging process of two convective rainbands along the two fronts. Gradients of $\theta$ and $q_{v}$ near the surface in the simulated results were consistent with those in the surface meteorological observations. In the following meso- $\alpha$-scale analyses using the simulated results, convective rainfalls along the "water vapor front," and the Baiu front, are called LINE1 and LINE2, respectively, as in the analyses in Part I.

Simulated rainfall areas and potential temperature $\theta$ fields with the $5 \mathrm{~km}-\mathrm{NHM}$ from $t=0 \mathrm{hr}$ (6 JST on 27 June) to $t=7 \mathrm{hr}$ (13 JST on 27 June) are shown in Fig. 5. The Baiu front and the "water vapor front" are indicated by symbols for a cold front and a stationary front, respectively. In a meso- $\alpha$-scale field, the Baiu front is defined as a convergence line with northerly and southerly winds, and has remarkable gradients of $\theta(2 \sim 3 \mathrm{~K}$ per $50 \mathrm{~km}) *$ and $q_{v}\left(2 \sim 3 \mathrm{~g} \mathrm{~kg}^{-1}\right.$ per $\left.50 \mathrm{~km}\right)$ at the surface.

* Over mountainous regions, high $\theta$ values are seen in the north of the Baiu front owing to using $z^{*}$ coordinate and the surface heating.
The "water vapor front" is defined as a weak convergence line with a remarkable moisture gradient (1-2 $\mathrm{g} \mathrm{kg}^{-1}$ per $10 \mathrm{~km}$ ) around a height of $0.5 \mathrm{~km}$ in the southerly wind field, as in Part I. For 3 hours from the initial time $(t=0-3 \mathrm{hr})$, the Baiu front was located 50$100 \mathrm{~km}$ north of the "water vapor front" (Figs. $5 \mathrm{a}-\mathrm{d})$, as shown in the reflectivity field at 0900 JST in Fig. 4a as well. During the 3 hours $(t=0-3 \mathrm{hr})$, both fronts were quasi-stationary in the north-south direction, and a meso- $\alpha$-scale cold pool in the north of the Baiu front appeared in association with the formation of the stratiform precipitation region. The $\theta$ gradient across the Baiu front intensified with the expansion of the cold pool.

After $t=4 \mathrm{hr}$, two convective rainfalls along the "water vapor front" and the Baiu front (marked as LINE1 and LINE2) were well simulated (Figs. 5e-h). From $t=4 \mathrm{hr}$ (10 JST) to $t=7 \mathrm{hr}$ (13 JST), a cold northerly outbreak advected from the cold pool to the Baiu front, and the Baiu front began to propagate southward. During the 3 hours $(t=4-7 \mathrm{hr}$ ), the cold pool developed continuously in the stratiform precipitation region. The Baiu front between $127^{\circ} \mathrm{E}$ and $130^{\circ} \mathrm{E}$ propagated rapidly southward over $50 \mathrm{~km}$ in association with the development of the cold pool. Because the "water vapor front" was quasi-stationary in the north-south direction, the two frontal convergence lines merged at $t=7 \mathrm{hr}$ (13 JST) as a result of the cold pool development. The intensity of rainfall along the "water vapor front" (LINE1) immediately increased from $1-20 \mathrm{~mm} \mathrm{~h}^{-1}$ to $30-50 \mathrm{~mm} \mathrm{~h}^{-1}$, due to the merger with a stronger convergence along the Baiu front. After the frontal merging, the "water vapor front" propagated southward with the Baiu front till the end of this simulation (not shown).

The behaviors of the Baiu front, and the "water vapor front," are summarized in Fig. 6. The Baiu front is accompanied by a weak precipitation band of BAND2 with a length of about $600 \mathrm{~km}$ and a stratiform precipitation region to the north. A meso- $\alpha$-scale cold pool formed in the stratiform precipitation region. LINE2 (a line-shaped intense rainfall area) developed in the eastern part of BAND2. The "water vapor front" is accompanied by BAND1 with a length of about $350 \mathrm{~km}$, and LINE1 was embedded in BAND1. Although the Baiu front 

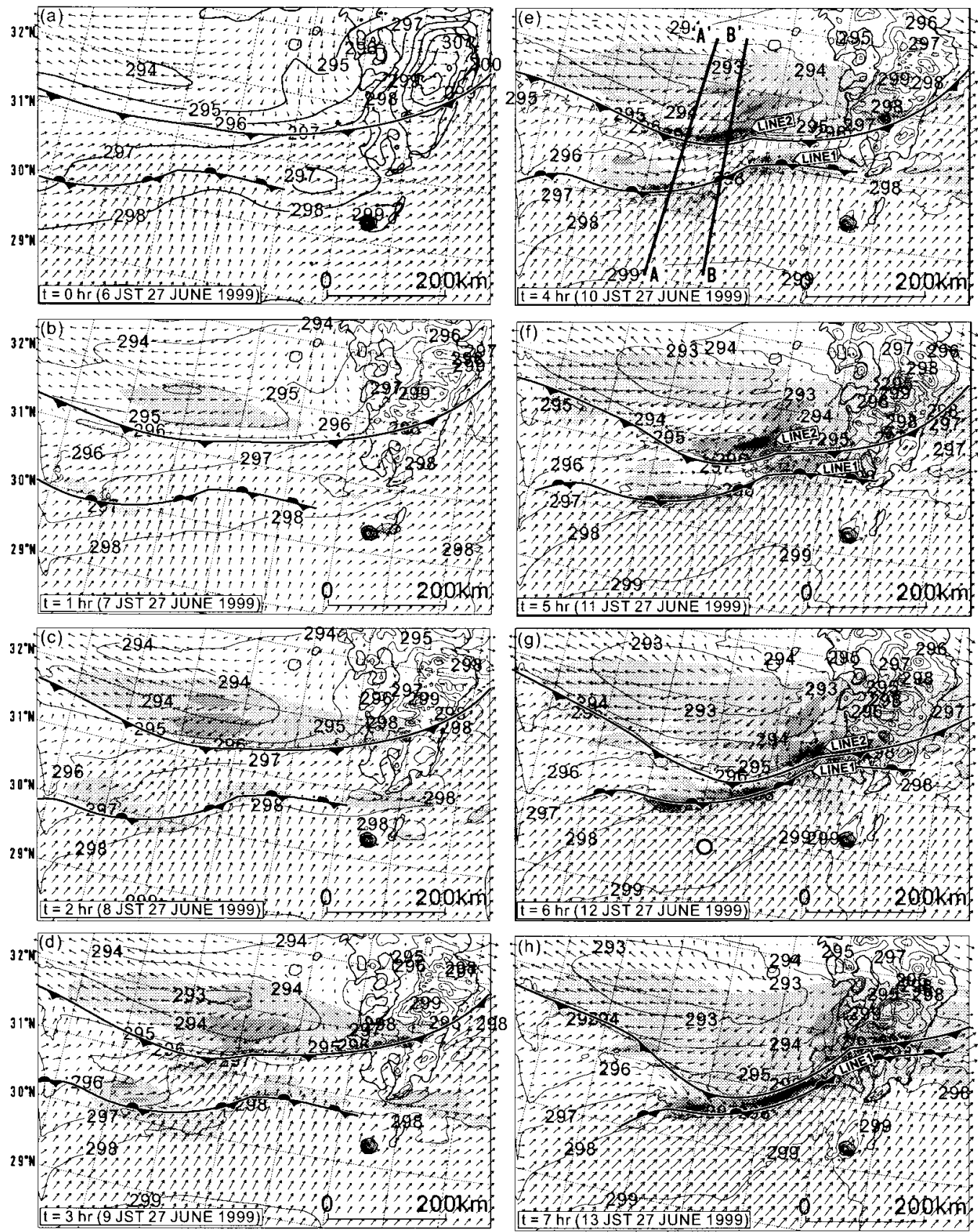

$\begin{array}{llllllll}126^{\circ} \mathrm{E} & 127^{\circ} \mathrm{E} & 120^{\circ} \mathrm{E} & 12 \mathrm{~g}^{\circ} \mathrm{E} & 130^{\circ} \mathrm{E} & 131^{\circ} \mathrm{E} & 132^{\circ} \mathrm{E} \\ \text { Rain } 1 & 10 & 20 & 30 & 40 & 50 & (\mathrm{~mm} / \mathrm{h})\end{array}$

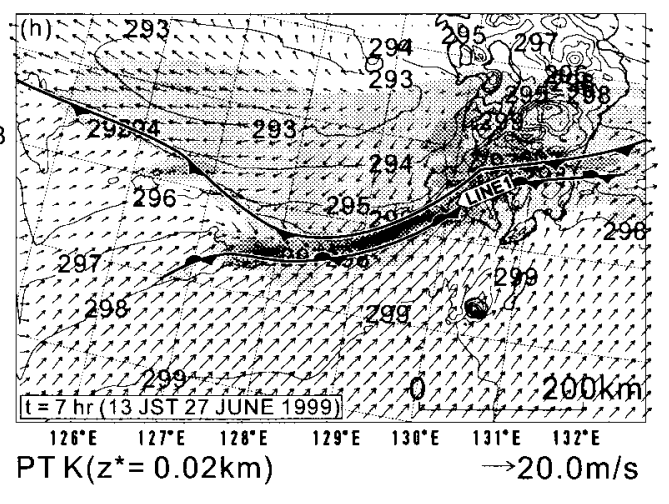

Fig. 5. The rainfall area (shaded), potential temperature (contours) and wind vectors reproduced by the $5 \mathrm{~km}-\mathrm{NHM}$ at a height of $0.02 \mathrm{~km}$ from $t=0$ hour ( $6 \mathrm{JST}$ ) to $t=7$ hour (13 JST). The open circle in (g) indicates the position of vertical profiles shown in Fig. 14(a). Lines of A-A' and B-B' in (e) indicate positions of vertical cross sections in Figs. 7, 9, and 10. 


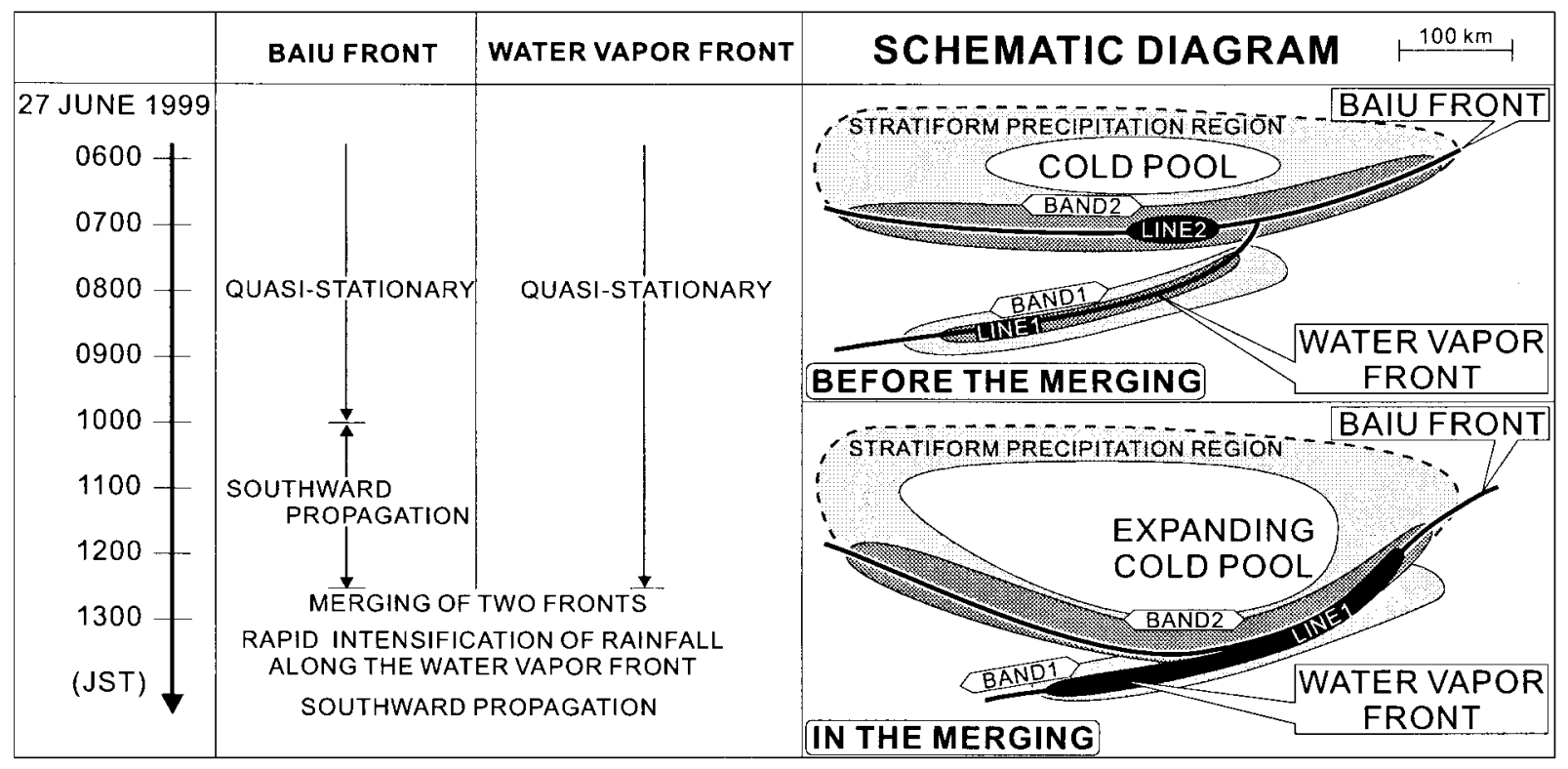

Fig. 6. The behaviors of the Baiu front and the "water vapor front" on 27 June 1999. Schematic diagrams of rainfall distributions before and in the frontal merging are also summarized in the right side. In the diagrams, the background shading denotes rainfall intensity. A stratiform precipitation region is surrounded by a dashed line. Precipitation bands along the "water vapor front" and the Baiu front are marked as BAND1 and BAND2, respectively. Intense convective rainfall areas along the two fronts are marked as LINE1 and LINE2, respectively.

was quasi-stationary till $1000 \mathrm{JST}$, its rapid southward propagation occurred in association with the expanding cold pool from 1000 JST to 1300 JST. The "water vapor front" was quasistationary till $1300 \mathrm{JST}$, and merged with the Baiu front at 1300 JST. After the frontal merging, the "water vapor front" also began to propagate southward. In association with the behaviors of the two fronts, the behaviors of LINE1 and LINE2 were seen as follows. LINE2 moved rapidly southward in association with the southward propagation of the Baiu front. At 1300 JST, LINE2 merged into the northeastern part of LINE1, and the rainfall intensity in LINE1 increased rapidly.

Vertical cross sections of vertical velocity along $\mathrm{A}-\mathrm{A}^{\prime}$ (the western side of intense convective rainfall of LINE2) and $\mathrm{B}^{-\mathrm{B}^{\prime}}$ (the center of LINE2) before the frontal merging $(t=4 \mathrm{hr})$ are shown in Fig. 7. The Baiu frontal surface is defined by considering the $\theta$ gradient and the horizontal wind direction of north-south component (see also Figs. 9 and 10). To the north of the Baiu front, a weak upslope flow $\left(<1 \mathrm{~m} \mathrm{~s}^{-1}\right)$ is seen above the Baiu frontal surface in both panels. The Baiu frontal structure is very shallow (less than $3 \mathrm{~km}$ between $250-400 \mathrm{~km}$ in these cross sections), as suggested in synopticscale analyses of Section 3. Although there is no significant difference of structure of the frontal surface between the two panels, the updraft at the Baiu front along $\mathrm{B}-\mathrm{B}^{\prime}\left(>8 \mathrm{~m} \mathrm{~s}^{-1}\right)$ is quite stronger than that along A-A $\left(<4 \mathrm{~m} \mathrm{~s}^{-1}\right)$. It is considered that the difference of the updraft strength is caused by that of diabatic heating, which could depend on a moisture supply from the south.

To study the moisture structure before the frontal merging, the simulated water vapor fields at $t=4 \mathrm{hr}$ (10 JST) are shown in Fig. 8. At a height of $0.02 \mathrm{~km}$ (Fig. 8a), a $q_{v}$ gradient across the eastern part of the Baiu front from $128^{\circ} \mathrm{E}\left(16 \sim 19 \mathrm{~g} \mathrm{~kg}^{-1}, 3 \mathrm{~g} \mathrm{~kg}^{-1}\right.$ per $\left.50 \mathrm{~km}\right)$ is more significant than that across the western part $\left(16 \sim 17 \mathrm{~g} \mathrm{~kg}^{-1}, 1 \mathrm{~g} \mathrm{~kg}^{-1}\right.$ per $\left.50 \mathrm{~km}\right)$. Although the $q_{v}$ gradient across the "water vapor front" is relatively small $\left(18 \sim 19 \mathrm{~g} \mathrm{~kg}^{-1}\right.$, less than $1 \mathrm{~g} \mathrm{~kg}^{-1}$ per $50 \mathrm{~km}$ ), that is more clearly seen at a height of $0.52 \mathrm{~km}$ (Fig. 8b), as described in Part I. The $q_{v}$ gradient across the 


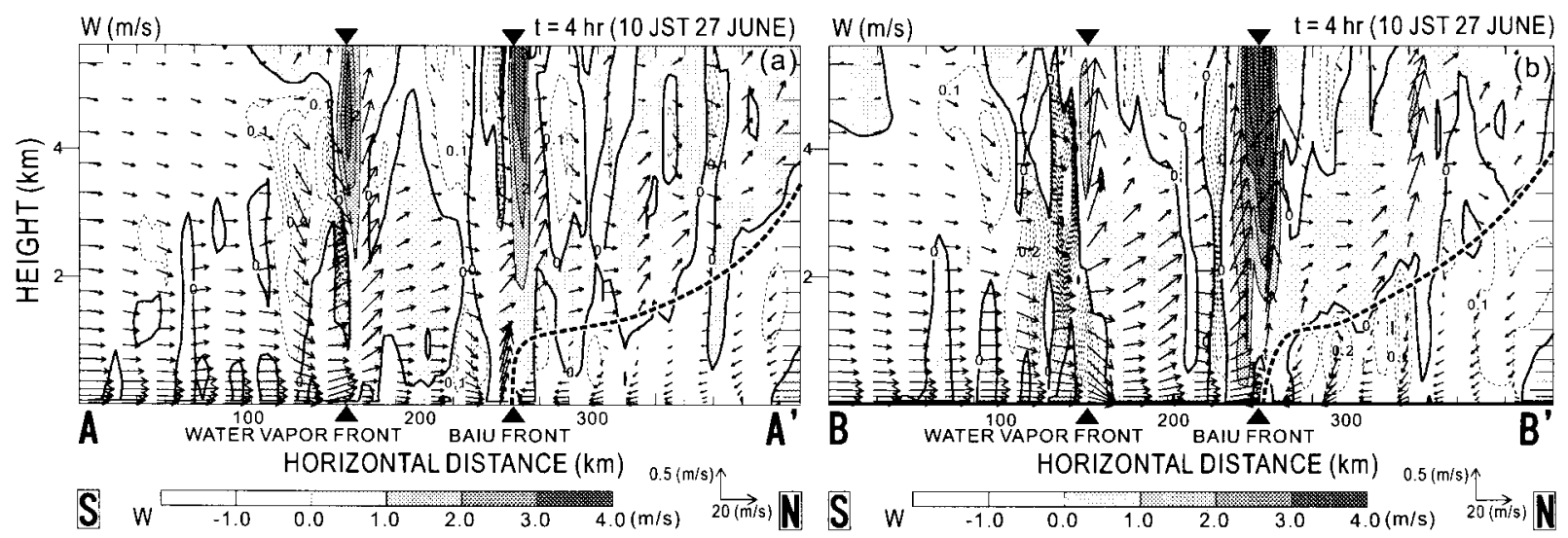

Fig. 7. Vertical cross sections of vertical velocity along (a) A-A' and (b) B-B' indicated in Fig. 5(e). The upward velocity (shaded and contoured by solid lines every $1 \mathrm{~m} \mathrm{~s}^{-1}$ ) and downward velocity (contoured by dashed lines every $0.1 \mathrm{~m} \mathrm{~s}^{-1}$ ) are shown. The bold dashed line represents the Baiu frontal surface.

"water vapor front" at the height of $0.52 \mathrm{~km}$ $\left(15.5 \sim 18 \mathrm{~g} \mathrm{~kg}^{-1}, 2-2.5 \mathrm{~g} \mathrm{~kg}^{-1}\right.$ per $\left.50 \mathrm{~km}\right)$ is accompanied by a weak convergence of moist $\left(16 \sim 18 \mathrm{~g} \mathrm{~kg}^{-1}\right)$ southwesterly and relatively dry $\left(\sim 15.5 \mathrm{~g} \mathrm{~kg}^{-1}\right)$ westerly winds at $0.52 \mathrm{~km}$. The $q_{v}$ gradient between the southwesterly and westerly flows extends to the west from $126^{\circ} \mathrm{E}$, but there are no convections. These features of the "water vapor front" was seen from the initial time (figure not shown). It was confirmed that the convergence along the "water vapor front" could form convections, but was not formed as a result of convections.

At a height of $2.88 \mathrm{~km}$, the "moist tongue" (> $10 \mathrm{~g} \mathrm{~kg}^{-1}$ ), with westerly winds, extends from the west to the southern Kyushu (Fig. 8c). The "moist tongue" was steadily seen with the same distribution for 9 hours in this simulation. The stationary distribution suggests that a large amount of water vapor is steadily supplied from the west at this altitude. The continuous moisture flux could be lifted with the upslope flow on the Baiu frontal surface shown in Fig. 7, and form the stratiform precipitation.

Vertical cross sections of potential temperature $\theta$, mixing ratios of rainwater $q_{r}$, and water vapor $q_{v}$ along $\mathrm{A}-\mathrm{A}^{\prime}$ and $\mathrm{B}-\mathrm{B}^{\prime}$ are shown in Fig. 9. In both panels, downward motion and a cold pool with a depth of about $1 \mathrm{~km}$ are seen to the north of the Baiu front, and a remarkable $\theta$ gradient is seen at the Baiu front (Figs. 9a and 9b). However, a significant difference in the moisture structure is found between both panels. Along A-A', a high $q_{v}$ air mass (> $16 \mathrm{~g} \mathrm{~kg}^{-1}$ ) is over $1-\mathrm{km}$ deep to the south of the "water vapor front," but its depth rapidly becomes shallow (less than $0.5 \mathrm{~km}$ ) between the two fronts $(180-220 \mathrm{~km})$. The $q_{r}$ at the Baiu front (LINE2) along $\mathrm{A}-\mathrm{A}^{\prime}$ is only about $2 \mathrm{~g} \mathrm{~kg}^{-1}$. On the contrary, along B-B', a high $q_{v}$ air mass of about 1-km depth reaches the Baiu front, and $q_{r}$ at the Baiu front (LINE2) is over $4 \mathrm{~g} \mathrm{~kg}^{-1}$. These structures indicate that the high $q_{v}$ air mass from the south below $1 \mathrm{~km}$ has a considerable contribution to the rainfall development at the Baiu front before the frontal merging. However, these results raise a significant question. Along A-A', the depth of the high $q_{v}$ air mass was very shallow between the two fronts although there was no remarkable downdraft, as shown in Fig. 7. Why does the high $q_{v}$ air mass become rapidly shallow between the two fronts along A-A'?

Figure 10 shows vertical cross sections of relative humidity $R h$ and wind velocity of $U$ and $V$ components along $\mathrm{A}-\mathrm{A}^{\prime}$ and $\mathrm{B}-\mathrm{B}^{\prime}$. The boundary of moist and dry air masses (the thick solid line) are defined by considering the threshold value of $R h=90 \%$ and the horizontal wind direction. A moist air mass to the south of the "water vapor front" below $2 \mathrm{~km}$ is dominated with southwesterly winds. Considering the results of the synoptic-scale analyses, the moist southwesterly air corresponds with the oce- 

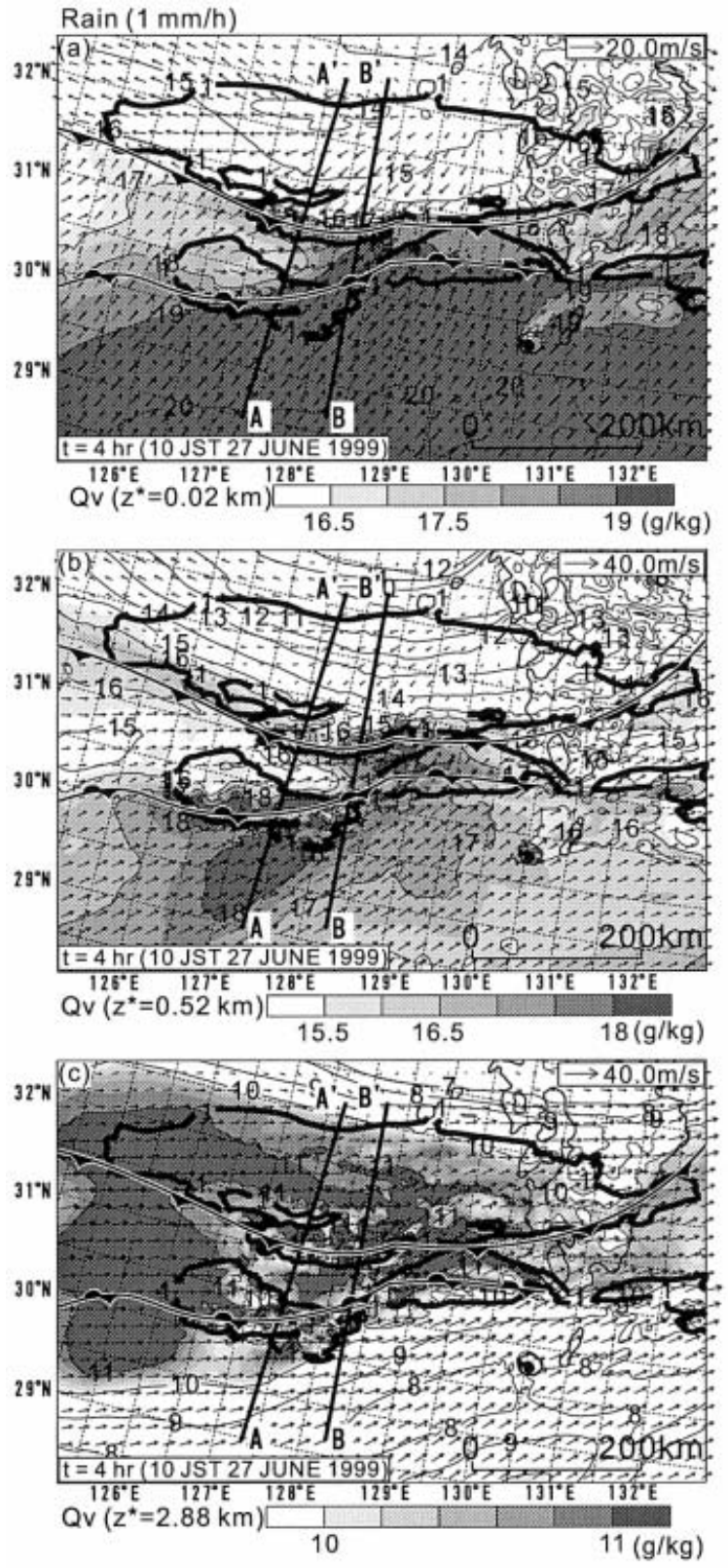

Fig. 8. Moisture fields reproduced by the $5 \mathrm{~km}-\mathrm{NHM}$ at a height of (a) $0.02 \mathrm{~km}$, (b) $0.52 \mathrm{~km}$, and (c) $2.88 \mathrm{~km}$ at $t=4 \mathrm{hr}$ (10 JST). Rainfall areas of $1 \mathrm{~mm} \mathrm{~h}^{-1}$ are shown by bold contours. Lines of $\mathrm{A}-\mathrm{A}^{\prime}$ and $\mathrm{B}-\mathrm{B}^{\prime}$ indicate positions of vertical cross sections in Figs. 9 and 10.

anic moist air shown in Fig. 3. This moist air mass could form as a result of development of the mixing layer over the ocean. Meanwhile, a moist air mass to the north of the "water vapor front" above $1.5 \mathrm{~km}$ is dominated with westerly winds. This moist air mass corresponds with the "moist tongue," and could result from the vertical mixing of the continental moist air from the west. The continental moist air has relative humidity more than $90 \%$, but its $q_{v}$ in the lower layer is smaller than that in the oceanic moist air (see Fig. 8a and 8b).

Along A-A', the northern head of a strong southerly component $\left(>6 \mathrm{~m} \mathrm{~s}^{-1}\right)$ is quite consistent with the position of the "water vapor front." The oceanic moist air mass along A-A' is blocked by the continental moist air mass above $1.5 \mathrm{~km}$ because these distinct air masses cannot mix horizontally. On the contrary, along B-B' near the eastern edge of the "moist tongue," the continental moist air mass narrows below $2 \mathrm{~km}$. The low-level convergence of the "water vapor front" along B-B' was much weaker than that along $\mathrm{A}-\mathrm{A}^{\prime}$, and the oceanic moist air mass could partially advect into the Baiu front.

A conceptual model of meso- $\alpha$-scale twofrontal structures over the eastern part of the East China Sea on 27 June 1999 is shown in Fig. 11. The "water vapor front" is a weak convergence line of oceanic southwesterly and continental westerly flows at heights around $0.5 \mathrm{~km}$ in the south of the Baiu front. Because the continental moist air has smaller $q_{v}$ than the oceanic moist air, the "water vapor front" is accompanied by a remarkable moisture gradient. The convergence along the "water vapor front" formed a long length rainband (LINE1) over the ocean far from land without any land effects.

Rainfall intensity was quite weak along the western part of the Baiu front because the oceanic moist air mass from the southwest was blocked by the continental moist air mass from the west. On the contrary, because the lowlevel convergence along the eastern part of the "water vapor front" was quite weak, the oceanic moist air flow could have partially advected into the Baiu front. Consequently, an intense rainband of LINE2 formed along the eastern part of the Baiu front.

The continental moist westerly flow could contribute little to the development of convective rainfall, but form and maintain a broad stratiform precipitation region. The stratiform precipitation region was formed over an up- 

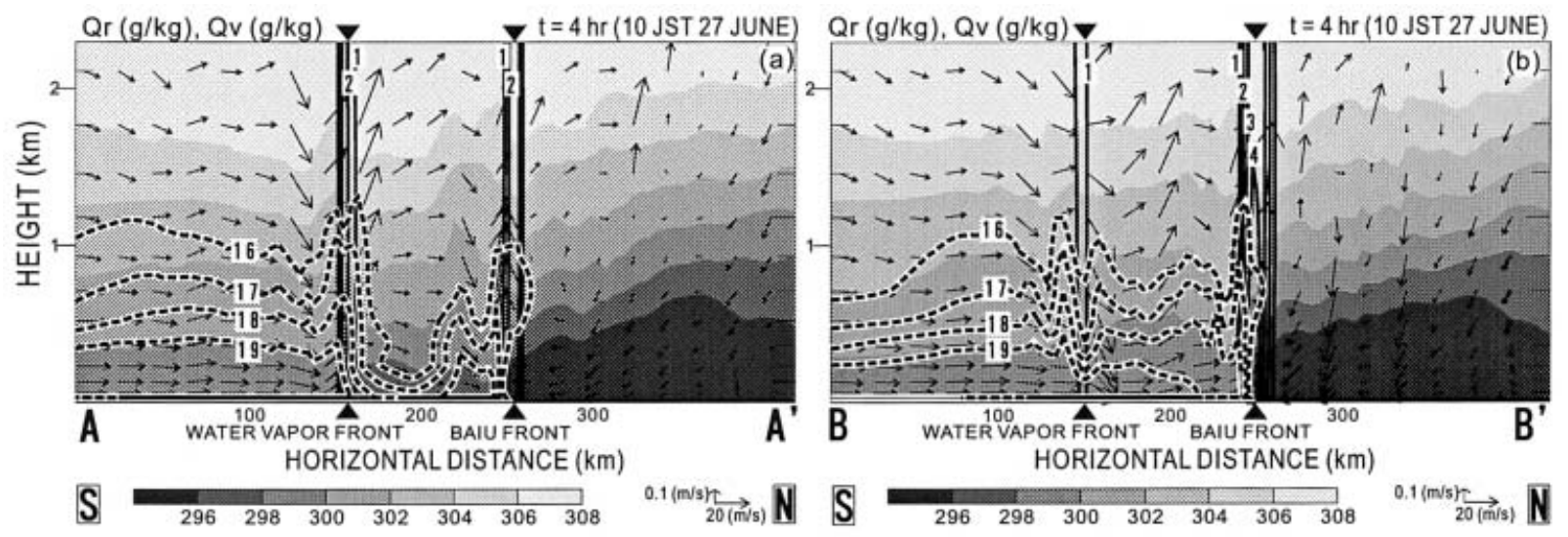

Fig. 9. Vertical cross sections along (a) A-A' and (b) B-B' indicated in Figs. 5(e) and 8. The potential temperature (shaded), the mixing ratio of rainwater over $1 \mathrm{~g} \mathrm{~kg}^{-1}$ (solid contours) and the mixing ratio of water vapor over $16 \mathrm{~g} \mathrm{~kg}^{-1}$ (dashed contours) are shown.

slope of a shallow synoptic-scale cold air mass (less than $3-\mathrm{km}$ deep). In the synoptic-scale cold air mass, a meso- $\alpha$-scale cold pool, with a depth of about $1 \mathrm{~km}$, formed in the stratiform precipitation region.

In these features of the meso- $\alpha$-scale field, it should be pointed out that the "water vapor front" is similar to the "dryline." The "dryline" is a weak convergence line along a boundary between the continental dry air mass over the Great Plains and the oceanic moist air mass from the Gulf of Mexico (Bluestein and Parker 1993). The definition of the "water vapor front" is almost the same as that of the "dryline," that is, a weak convergence line with a remarkable moisture gradient between oceanic and continental air masses. It is well known that the convergence along the "dryline" triggers convections (e.g., Carl et al. 1997). Similarly to the "dryline," the "water vapor front" can form a convective rainband, but the convergence and a large moisture gradient along the "water vapor front" are not the result of convections.

\section{Build-up processes of convergence}

A rainfall along the "water vapor front" was intensified by merging with a stronger convergence along the Baiu front, as shown in the analyses in Section 4 and Part I. However, the low-level convergence along the Baiu front was quite weak in the initial field of the experiment with the $5 \mathrm{~km}-\mathrm{NHM}$ (see Fig. 5a). The low-level convergence along the Baiu front was clearly intensified before the frontal merging. It was considered that two mesoscale processes associated with the cold pool, and decreased pressure, contributed to the intensification of the low-level convergence. In this section, in order to study effects of the cold pool and decreased pressure, horizontal wind velocity fields around the two fronts near the surface were investigated.

\subsection{Cold pool effects}

Because relatively dry air $(R h<80 \%)$ was found $150 \mathrm{~km}$ north of the Baiu front below a height of $3 \mathrm{~km}$ in Figs. 10a and 10b, the cold pool could be formed by evaporative cooling in the stratiform precipitation region. In order to investigate the effects of the cold pool, a sensitivity experiment with the $5 \mathrm{~km}-\mathrm{NHM}$ without evaporation of raindrops (hereafter, this experiment is called NOEVP) was performed in addition to a control experiment (CNTL). In the RSM simulation, the cold pool began to form at 06 JST on 27 June which was the initial time of the CNTL. The southward propagation of the Baiu front is possible to be induced by not only the cold pool development, but also a southward motion of the synoptic-scale cold air mass. It is necessary to eliminate the cold pool in the initial field of the NOEVP for separating influences of the cold pool and the synoptic-scale cold air mass. For eliminating the cold pool in the NOEVP, the NOEVP was nested from 03 

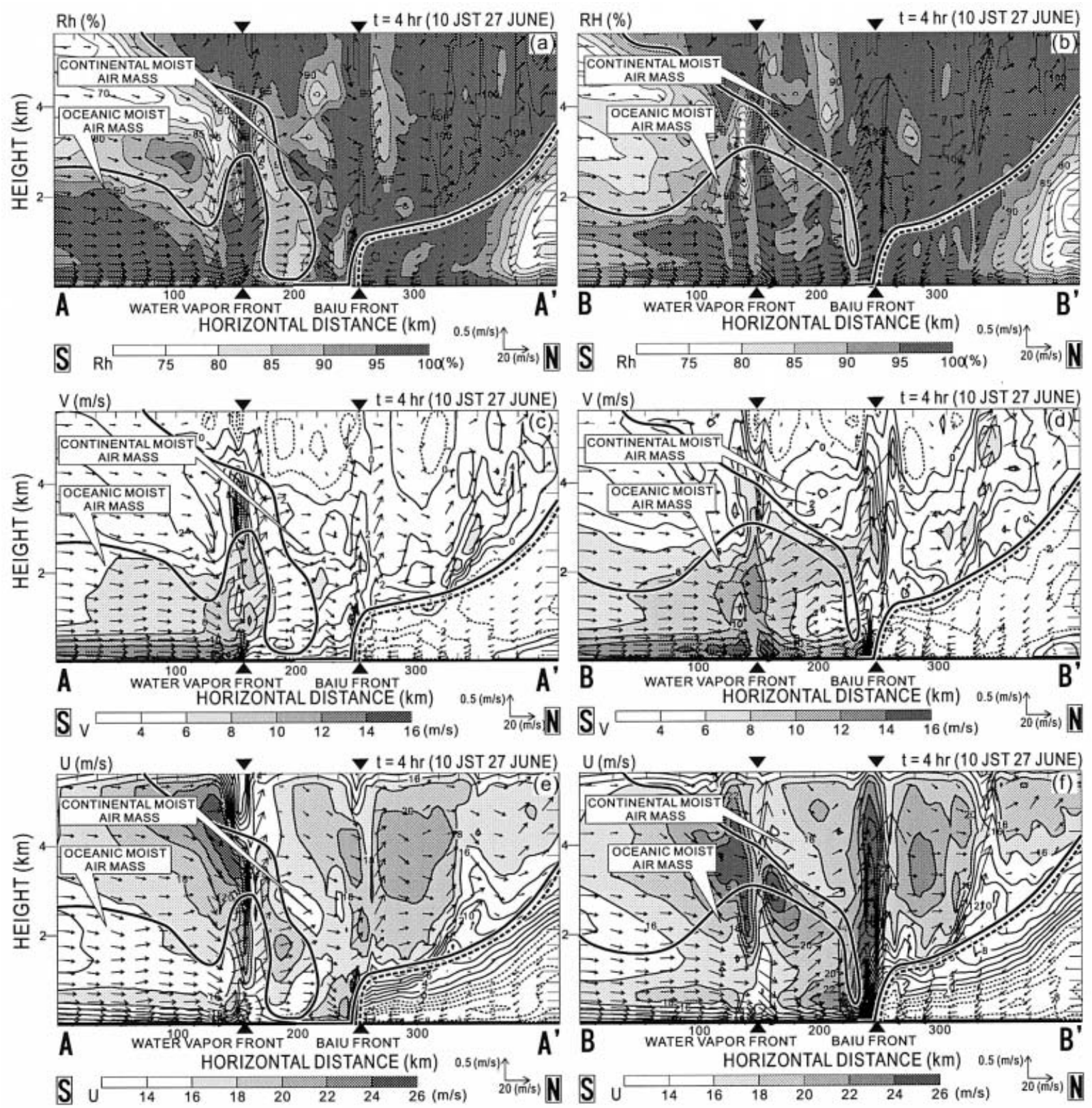

Fig. 10. Vertical cross sections along (a) A-A' and (b) B-B' indicated in Figs. 5(e) and 8. (a) and (b) the relative humidity (contoured every $5 \%$ and shaded over $80 \%$ ), (c) and (d) north-south component of wind (contoured every $2 \mathrm{~m} \mathrm{~s}^{-1}$ and shaded over $6 \mathrm{~m} \mathrm{~s}^{-1}$ ), and (e) and (f) east-west component of wind (contoured every $2 \mathrm{~m} \mathrm{~s}^{-1}$ and shaded over $16 \mathrm{~m} \mathrm{~s}^{-1}$ ). The thick solid line represents the boundary of moist and dry air masses. The thick dashed line represents the Baiu frontal surface.

JST 27 June before the formation of the cold pool. For 3 hours from $t=0 \mathrm{hr}(03-06 \mathrm{JST})$ in the NOEVP, the cold pool was removed completely from a synoptic-scale cold air mass. At
06 JST, the closed contour of $294 \mathrm{~K}$ shown in the CNTL is not seen in the NOEVP (Fig. 12e). The positions of the two fronts, the $\theta$ gradient of the Baiu front (about $2 \mathrm{~K}$ per $50 \mathrm{~km}$ ), and 


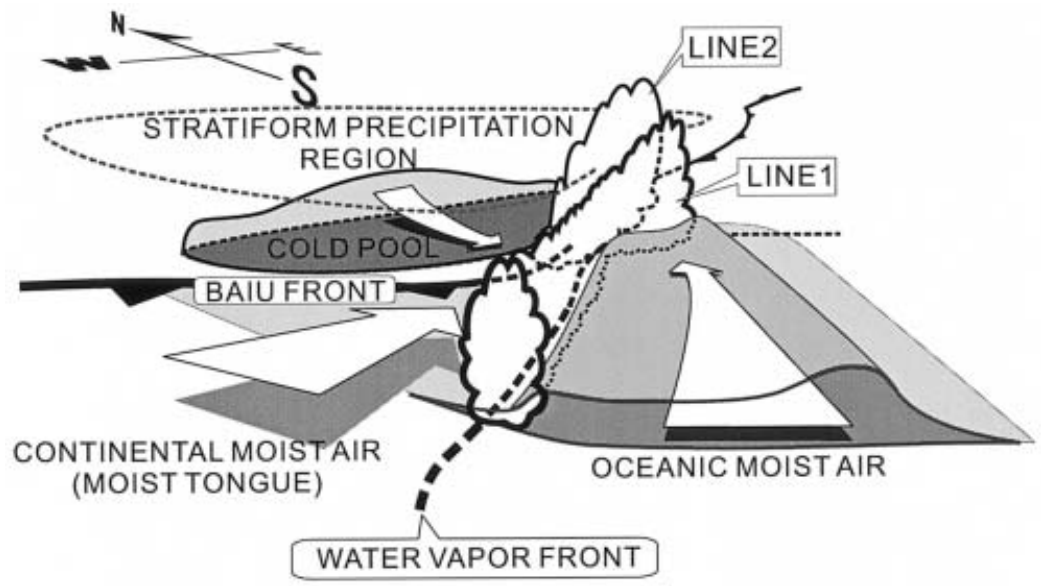

Fig. 11. A conceptual model of the meso- $\alpha$-scale structure of the circumstances of the Baiu front and the "water vapor front" on 27 June 1999. The meso- $\alpha$-scale cold pool in the north of the Baiu front is indicated by the dark shaded area. The thin dashed line in the north of the Baiu front indicates the stratiform precipitation region. The light shaded area to the south of LINE1 shows the oceanic southwesterly moist air mass below $2 \mathrm{~km}$. The "water vapor front" is indicated by the thick dashed line in the south of the Baiu front. The westerly arrow between the Baiu front and the "water vapor front" indicates the continental moist air.

the velocity of northerly winds in the NOEVP, are almost the same as they are in the CNTL (Figs. 12a and 12e).

From 06 JST to 12 JST in the CNTL, the velocity of northerly winds along the south edge of the cold pool increases by $2-4 \mathrm{~m} \mathrm{~s}^{-1}$ in association with an expansion of the cold pool (Figs. 12a-d). The wide part of the convergence along the Baiu front (over $500 \mathrm{~km}$ wide) is continuously enhanced by the accelerated northerly winds over the ocean. The Baiu front propagated rapidly southward about $50 \mathrm{~km}$ in the 2 hours from 10 JST to 12 JST (Fig. 12d). On the contrary, in the NOEVP, a mesoscale cold pool has never formed in the 6 hours from 06 JST to 12 JST, and a continuous acceleration of northerly winds along the Baiu front did not occur (Figs. 12e-h). The Baiu front in the NOEVP was quasi-stationary in the northsouth direction.

The sensitivity experiment without evaporation of raindrops confirms that the cold pool is created by an evaporation cooling of raindrops. This experiment reveals the two effects of the development of a cold pool. The cold pool continuously enhanced the low-level convergence along the Baiu front with a width exceeding $500 \mathrm{~km}$. Furthermore, the cold pool induced a rapid southward propagation of the Baiu front about $50 \mathrm{~km}$ in 2 hours.

\subsection{Acceleration of moist southerly winds}

A process of decreased pressure associated with diabatic heating mainly accelerates moist southerly winds, and there is a positive feedback between intensifications of convective rainfall and low-level convergence. Because a large moisture supply from the south is needed for driving the process, the acceleration of the southerly winds should be closely related to the moisture field. This subsection focuses on the horizontal extension of the area of the accelerated southerly winds, and intensity of the acceleration.

Horizontal wind velocity at a height of $0.02 \mathrm{~km}$ is shown in Fig. 13. Contours in Figs. $13 \mathrm{a}$ and $13 \mathrm{~b}$ indicate sea level pressure and pressure perturbation at that height, respectively. The pressure perturbation is defined as a difference from the basic state*, which is held constant during the time integration of the

* In the MRI-NHM, the pressure perturbation $p^{\prime}\left(x, y, z^{*}\right)$ is calculated rather than the total pressure $p\left(x, y, z^{*}\right) . p^{\prime}$ is defined as $(p-\bar{p}(z))$. $\frac{z t}{z t-z s}$, where $\bar{p}(z)$ is obtained by averaging the pressure horizontally in the initial state. 

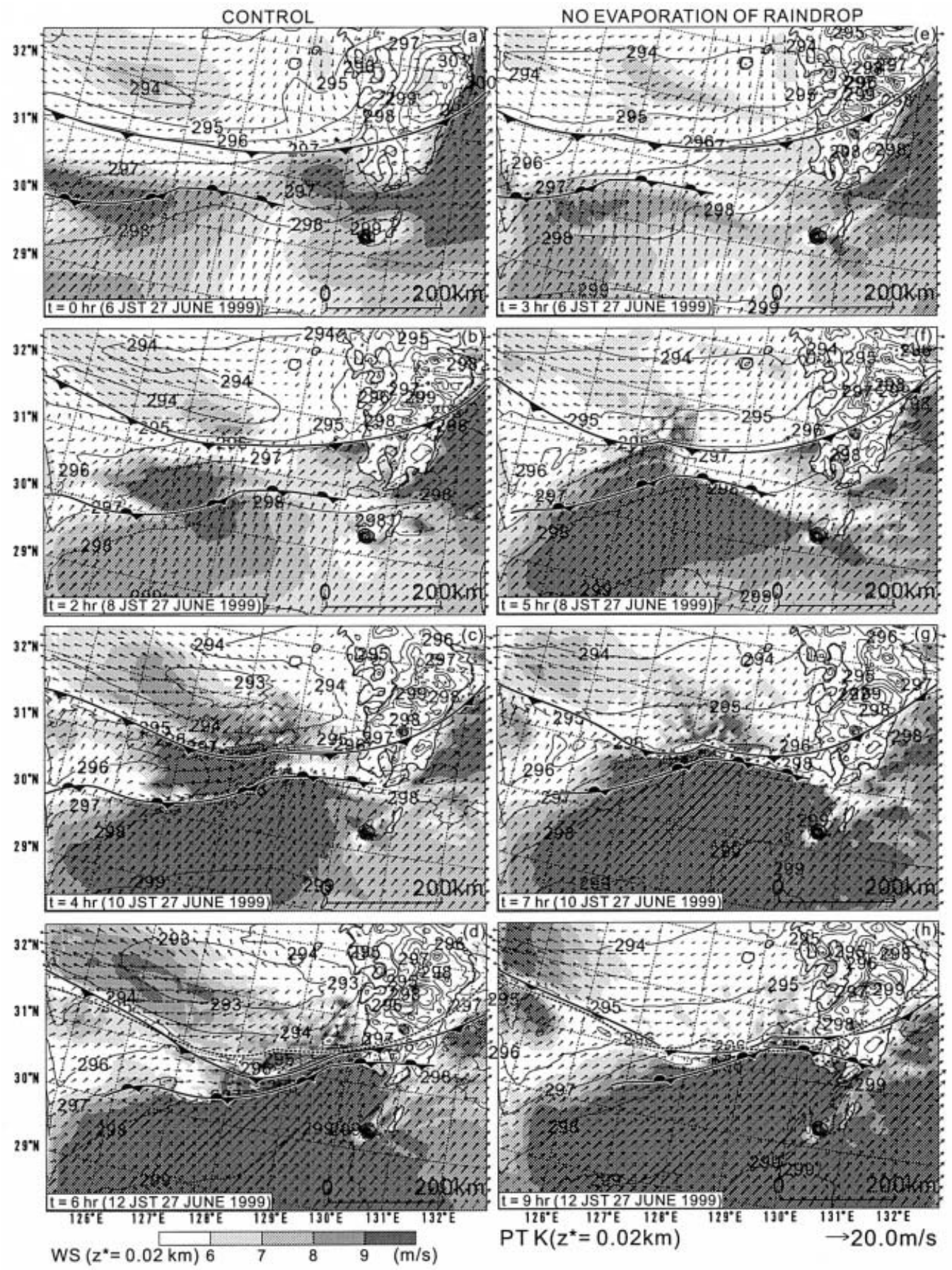

Fig. 12. Horizontal fields of wind speed at a height of $0.02 \mathrm{~km}$ from 06 JST to $12 \mathrm{JST}$ reproduced by the CNTL in the left panels and the NOEVP in the right panels. The contours indicate the potential temperature at a height of $0.02 \mathrm{~km}$. The dashed lines shown in (d) and (h) represent the positions of the Baiu front in (c) and (g), respectively. 


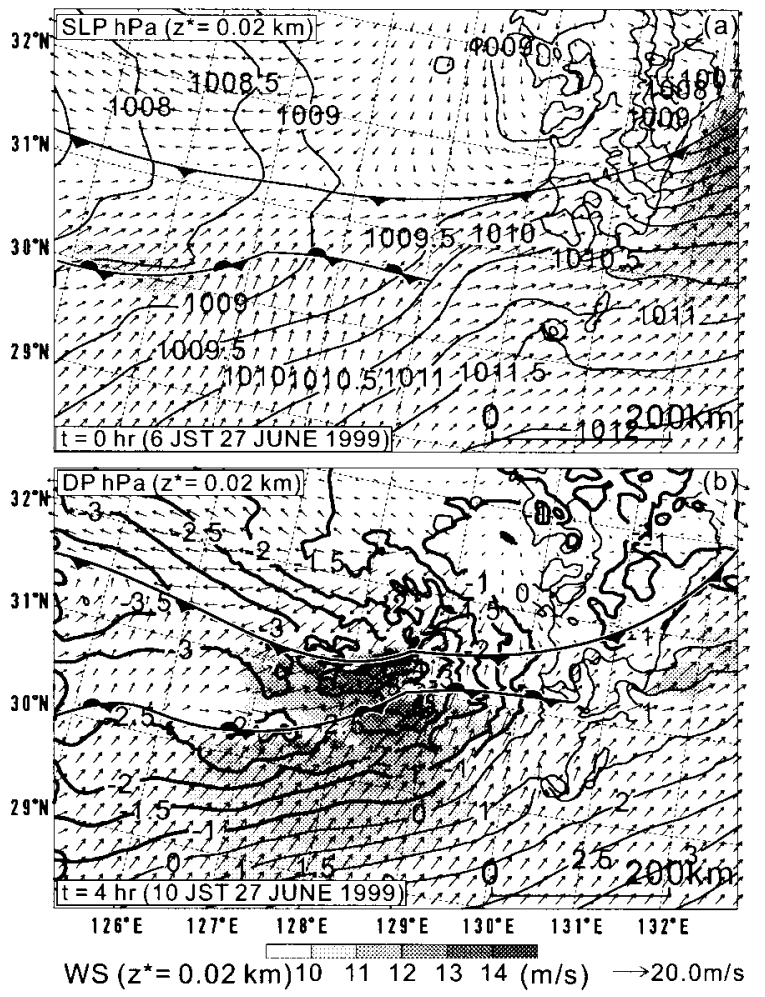

Fig. 13. Horizontal fields of wind speed reproduced by the $5 \mathrm{~km}-\mathrm{NHM}$ at a height of $0.02 \mathrm{~km}$, (a) at $t=0 \mathrm{hr}(06$ JST) and (b) $t=4 \mathrm{hr}$ (10 JST). The contours indicate sea level pressure in (a) and perturbation pressure (negative: thick, positive: thin) in (b) at a height of $0.02 \mathrm{~km}$.

model. In the initial sea level pressure field, a weak pressure trough of the Baiu frontal region, including the two frontal structures, extends from the west to $31^{\circ} \mathrm{N}$ and $128^{\circ} \mathrm{E}$ (Fig. 13a). The southerly winds flowing into the Baiu front, and the "water vapor front" are generally less than $10 \mathrm{~m} \mathrm{~s}^{-1}$.

After $t=4 \mathrm{hr}$, decreases of pressure are induced along the Baiu front and the "water vapor front" (Fig. 13b). The decreases of 2$2.5 \mathrm{hPa}$ and $3-4 \mathrm{hPa}$ are seen corresponding to the convective rainfall areas of LINE1 and LINE2, respectively. Southerly winds in the south of LINE1 and LINE2 are greatly accelerated over $5 \mathrm{~m} \mathrm{~s}^{-1}$ by the enhanced pressure gradient force around the decreased pressure. The acceleration of southerly winds is larger than that of northerly winds associated with the cold pool. However, the horizontal extension of the area of the accelerated southerly winds $\left(>12 \mathrm{~m} \mathrm{~s}^{-1}\right)$ is only about $200 \mathrm{~km}$ wide in the west-east direction. This horizontal scale is considerably smaller than that of the accelerated northerly winds (over $500 \mathrm{~km}$ wide). The scale of the area of the accelerated southerly winds seems to depend on a distribution of the high $q_{v}$ air $>19 \mathrm{~g} \mathrm{~kg}^{-1}$ near the surface (see Fig. 8a). The acceleration of the southerly winds occurs only in the area where the high $q_{v}$ (oceanic moist) air is supplied.

To investigate the characteristics of the accelerated southerly wind near the surface, vertical profiles of wind in the south of LINE1 are shown in Fig. 14. The profiles from the Keifu Maru sounding at 1130 JST are shown for a verification of those with the $5 \mathrm{~km}-\mathrm{NHM}$. In the upper layer above $6 \mathrm{~km}$, the velocities of the $V$ component in the profiles of the $5 \mathrm{~km}-\mathrm{NHM}$ are negative, differing from those from the Keifu Maru sounding. The difference could be due to the radiosonde balloon drifted on the lee-side of the location of Keifu Maru in the upper layer. On the lee-side, the $5 \mathrm{~km}-\mathrm{NHM}$-simulated velocities of $V$ component was positive at upper levels, as shown in the observed profile as well. In the lower layer, the profiles of both the observed and simulated winds show almost the same features. At a height of $0.5 \mathrm{~km}$, a peak of strong velocity of about $20 \mathrm{~m} \mathrm{~s}^{-1}$, which consists of a $U$ component over $15 \mathrm{~m} \mathrm{~s}^{-1}$ and a $V$ component over $10 \mathrm{~m} \mathrm{~s}^{-1}$, is seen in each profile. This peak could be due to an acceleration associated with decreased pressure. Especially, a large $V$ (front-normal) component over $10 \mathrm{~m} \mathrm{~s}^{-1}$ is visible below $0.5 \mathrm{~km}$. A moisture supply from the south in the layer below $0.5 \mathrm{~km}$ is found to be the most important for development of intense convective rainfall.

\section{Multiscale structures of the Baiu frontal region}

In the previous sections, the synoptic-scale and meso- $\alpha$-scale structures of the thermodynamic and moisture fields around the two fronts have been explained in detail. In addition, the meso- $\beta$-scale structure of two rainbands along the two fronts have been shown in Part I. The results in these analyses provide a reliable basis for a discussion of multiscale structures 


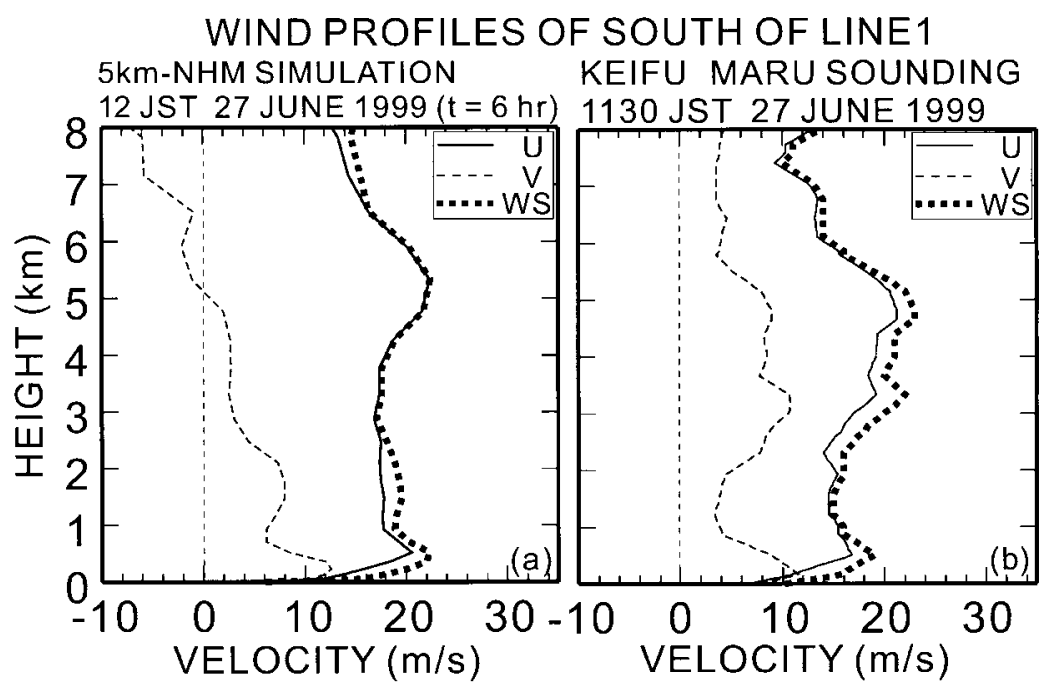

Fig. 14. Vertical profiles of east-west (solid) wind component and north-south (dashed) wind component, and horizontal wind speed (thick dotted). (a) Profiles with the simulated result of the $5 \mathrm{~km}$ NHM at $t=6 \mathrm{hr}$ (12 JST) at the grid point corresponding to the open circle shown in Fig. 5(g), (b) profiles at Keifu Maru $\left(30.65^{\circ} \mathrm{N}, 127.98^{\circ} \mathrm{E}\right)$ at $1130 \mathrm{JST}$. The relation between positions of LINE1 and the grid point in the simulated field with the $5 \mathrm{~km}-\mathrm{NHM}$ at $12 \mathrm{JST}$ (Fig. $5 \mathrm{~g}$ ) is almost the same as that between positions of BAND1 and Keifu Maru in reflectivity field with C-band radars at 1130 JST (Fig. 4b).

of the Baiu frontal region including the two fronts and the two rainbands.

Ninomiya and Akiyama (1992) pointed out that the Baiu frontal region had respective features in the hierarchy of synoptic-scale, meso$\alpha$-scale, meso- $\beta$-scale, and meso- $\gamma$-scale. However, it was very difficult to study the detailed multiscale structures of the Baiu frontal precipitation systems using various types of data (spatial and temporal resolutions and meteorological variables) because mesoscale data were generally poor, in particular, over the ocean. In a field experiment of the X-BAIU-99, the meso- $\beta$-scale (X-band Dopper radars) and meso$\alpha$-scale (a high-resolution network of upperair sounding, C-band radars) data of the Baiu frontal precipitation systems were obtained. Observational analyses using the data examined behaviors and airflow structure of two merged rainbands that had developed over the ocean on 27 June 1999. In addition, because simulated results of the two rainbands with the RSM and $5 \mathrm{~km}-\mathrm{NHM}$ were quite consistent with the results of the observational analyses, thermodynamic and moisture structures around the two rainbands in synoptic-scale, meso- $\alpha$-scale and meso- $\beta$-scale fields were also clarified. Here, we discuss the multiscale structures of the Baiu frontal region in comparison with the traditional schematic illustrations and our conceptual models.

Figures $15 \mathrm{a}, 15 \mathrm{~b}$ and $15 \mathrm{c}$ are the traditional schematic illustrations*. In the illustrations, multiscale features in the Baiu frontal region are mainly represented for rainfall distributions. In a large-scale precipitation area extending from China to the eastern sea of Japan (a shaded area in Fig. 15a), well-organized clusters of precipitation systems are seen in association with synoptic-scale or meso- $\alpha$-scale cyclones (shaded and hatched areas in Fig. 15b). The precipitation systems consist of a few meso- $\beta$-scale convective rainfall areas (light and dark shaded areas in Fig. 15c). Based on this concept of multiscale features, several observational and numerical studies over the past

* These illustrations are adopted from Ninomiya and Akiyama (1992) but partially modified by Shimizu (1996). 

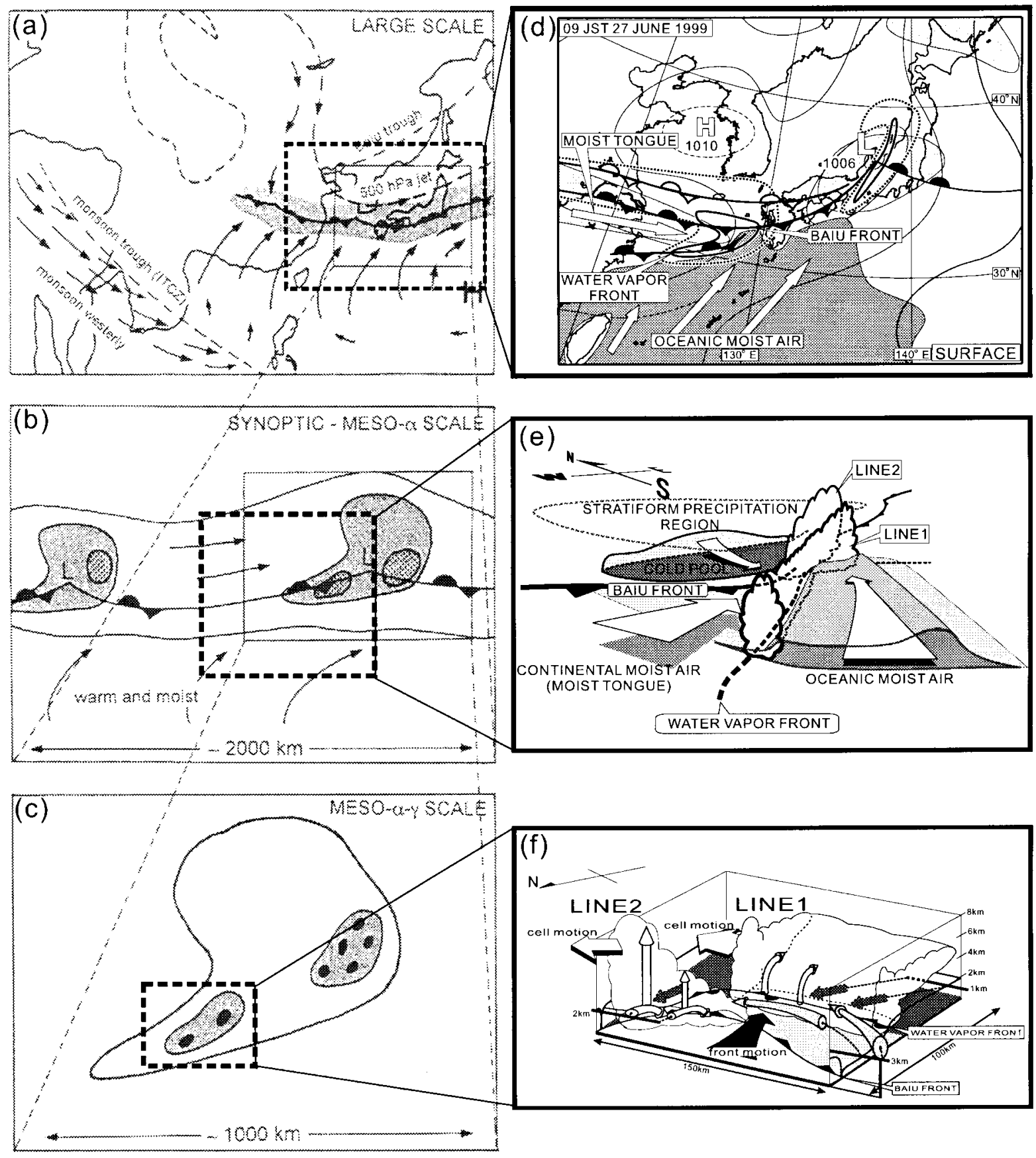

Fig. 15. The traditional schematic illustrations of the multiscale structure of the Baiu frontal region [adopted from Ninomiya and Akiyama (1992) but partially modified by Shimizu (1994)] are shown in the left-hand panels. The conceptual models of (d) the Baiu frontal region, (e) the Baiu front and the "water vapor front," and (f) the two rainbands on 27 June 1999 are shown in the right-hand panels. 
decade have presented three-dimensional structures and development processes of the Baiu frontal precipitation systems. However, the reason that the Baiu frontal region has a hierarchy of rainfall distributions has not been explained in the previous studies.

In the traditional illustrations, the moisture supply into the Baiu frontal region from the south (indicated by arrows) is almost homogeneously represented (Figs. $15 \mathrm{a}$ and $15 \mathrm{~b}$ ). Whereas, in the RSM-simulated field on 27 June 1999, the moisture supply into the Baiu frontal region is inhomogeneous over the East China Sea. The oceanic moist air (a dark shaded area in Fig. 15d) mainly flowed into the eastern part of the Baiu front over the East China Sea. In the precipitation area over the East China Sea, the two convective rainbands developed along the Baiu front and the "water vapor front."

Analyses using the $5 \mathrm{~km}-\mathrm{NHM}$ showed that, in the south of the Baiu front, the continental moist air flowed from the west over the western part of the East China Sea (Fig. 15e). The continental moist air blocked the supply of large moisture into the Baiu front with the oceanic moist air. Owing to the distributions of the oceanic and continental moist air masses, convective rainfall along the Baiu front was localized with a length of less than $100 \mathrm{~km}$ (Fig. 15f), as shown by observational analyses using X-band Doppler radars in Part I. Instead, a rainband with the length more than $150 \mathrm{~km}$ formed along the "water vapor front" in the south of the Baiu front.

Additionally, the analyses using the $5 \mathrm{~km}$ NHM revealed that the multiscale features were seen in a cold air mass to the north of the Baiu front. The center of high pressure associated with synoptic-scale cold air was located over $500 \mathrm{~km}$ north of the Baiu front $\left(125^{\circ} \mathrm{E}, 35-37^{\circ} \mathrm{N}\right)$, as shown in Fig. $15 \mathrm{~d}$. In the synoptic-scale cold air, a meso- $\alpha$-scale cold pool (500 km wide) was created 50-150 km north of the Baiu front by evaporation cooling of raindrops in a stratiform precipitation region (Fig. 15e). The meso- $\alpha$-scale cold pool induced a rapid southward propagation of the Baiu front (Fig. 15f).

In our case, a hierarchy of the rainfall distributions depended considerably on an inhomogeneous moisture supply from the south into the
Baiu frontal region. The inhomogeneousness of moisture supply from the south was due to the distributions of the oceanic and continental moist air masses. The distributions of the two moist air masses could be attributed to the location and influence of the subtropical high pressure. In the north of the Baiu front, a meso$\alpha$-scale cold pool was created in a synoptic-scale cold air mass. The cold pool made a considerable contribution to the southward propagation of the Baiu front.

\section{Conclusions}

In the present study, which is a two part series, the two merged rainbands on 27 June 1999 were examined with mutiscale analyses, using the data of the X-BAIU-99 observations and numerical simulations. Southern (LINE1) and northern (LINE2) rainbands were observed over the eastern part of the East China Sea far from land without any land effects. LINE1 and LINE2 formed along a weak convergence line in the southerly wind field and the Baiu front, respectively. From the meso- $\beta$-scale analyses in Part I, the weak convergence line was accompanied by a large moisture gradient, and named a "water vapor front." This paper described meso- $\alpha$-scale behaviors and structures of the two fronts. In addition, build-up processes of the frontal convergence associated with the cold pool and diabatic heating were investigated.

The "water vapor front" in the RSMsimulated field extends from the eastern coast of China with a length of about $1000 \mathrm{~km}$. From analyses of meso- $\alpha$-scale fields simulated by the $5 \mathrm{~km}-\mathrm{NHM}$, the "water vapor front" is a weak convergence line with oceanic southwesterly and continental westerly flows. Because the continental moist air has smaller $q_{v}$ than the oceanic moist air, the "water vapor front" is accompanied by a remarkable moisture gradient. The convergence along the "water vapor front" can form a long length rainband in a southerly wind field without any land effects.

Rainfall intensity along the western part of the Baiu front was quite weak, because the oceanic moist air mass was blocked at the "water vapor front" by the continental moist air mass. On the contrary, because the low-level convergence of the eastern part of the "water vapor front" was quite weak, the oceanic moist 
air could have partially advected into the Baiu front. Consequently, strong convective rainfall of LINE2 could develop along the eastern part of the Baiu front.

To the north of the Baiu front, a moisture supply with the continental moist air from the west formed and maintained a broad stratiform precipitation region. A meso- $\alpha$-scale cold pool formed in the stratiform precipitation region. Its southward expansion continuously intensified the low-level convergence along the Baiu front with a width exceeding $500 \mathrm{~km}$. A sensitivity test for the evaporation effect confirmed that the cold pool was created by an evaporation cooling of raindrops. After the cold pool developed sufficiently, its further expansion induced a rapid southward propagation of the Baiu front (about $50 \mathrm{~km}$ in 2 hours). It is found that the development of the cold pool induces the frontal merging, that is, the cause of the merging process of the two rainbands is the development of the cold pool.

In the areas of the southern side of the two fronts, southerly winds were greatly accelerated over $5 \mathrm{~m} \mathrm{~s}^{-1}$ by the pressure gradient force enhanced near the convective rainfalls of LINE1 and LINE2. The acceleration of southerly winds made a larger quantitative contribution to the enhancement of the low-level convergence than that of the northerly winds with the cold pool development. However, the horizontal extension of the area of the accelerated southerly winds (about $200 \mathrm{~km}$ wide) was considerably smaller than that of the accelerated northerly winds (over $500 \mathrm{~km}$ wide).

Multiscale analyses through this two-part series revealed the multiscale structures of the Baiu frontal region, including the two fronts and the two rainbands. Airflow, thermodynamic and moisture structures were represented in conceptual models. We propose that a hierarchy of rainfall distributions in the Baiu frontal region depends heavily on an inhomogeneousness of moisture supply from the south.

This paper confirmed the detailed structure of the "water vapor front," which was found in Part I. The "water vapor front" had substantial influences on the development of the Baiu frontal rainband, and the hierarchical rainfall distributions. In future studies, the processes involved in the origin and formation of the "water vapor front" will need to be investigated in synoptic-scale fields. It will be especially important to collect observational evidence of the "water vapor front" over the East China Sea (e.g., in situ observation by aircraft, water vapor profilers, aero-sondes, and Doppler radar mounted on research vessels).

\section{Acknowledgments}

The authors thank all of the participants in the X-BAIU-99 observation for obtaining these data and the Japan Meteorological Agency for providing sounding data and radar data. This study was supported by the Japan Science and Technology Corporation, and a Grant-in-Aid for Scientific Research of the Japan Society for the Promotion of Science. The numerical simulations were performed on the Hitachi SR8000 at the Hokkaido University Computing Center.

\section{References}

Akiyama, T., 1973: The large-scale aspects of the characteristics features of the Baiu front. Pap. Meteor. Geophy., 24, 157-188.

Bluestein, H.B. and S.S. Parker, 1993: Modes of isolated, severe conveective storm formation along the dryline. Mon. Wea. Rev., 121, 13521374.

Carl, H.E., H.B. Bluestein, T.M. Crawford, M.E. Baldwin and R.M. Rabin, 1997: Severe thunderstorm development in relation to alongdryline variability: A case study. Mon. Wea. Rev., 125, 231-251.

Chen, S.-J., Y.-H. Kuo, W. Wang, Z.-Y. Tao and B. Cui, 1998: A modeling case study of heavy rainstorms along the Mei-Yu front. Mon. Wea. Rev., 126, 2330-2351.

Ding, Y.-H., 1992: Summer monsoon rainfalls in China. J. Meteor. Soc. Japan, 70, 337-396.

Ishihara, M., Y. Fujiyoshi, A. Tabata, H. Sakakibara, K. Akaeda and H. Okumura, 1995: Dual Doppler radar analysis of an intense mesoscale rainband generated along the Baiu front in 1988: Its kinematical structure and maintenance process. J. Meteor. Soc. Japan, 73, 139163.

Kato, T., 1998: Numerical simulation of the bandshaped torrential rain observed over southern Kyushu, Japan on 1 August 1993. J. Meteor. Soc. Japan, 76, 97-128.

Moteki, Q., H. Uyeda, T. Maesaka, T. Shinoda, M. Yoshizaki and T. Kato, 2003: Structure and development of two merged rainbands observed over the East China Sea during X-BAIU-99 Part I: Meso- $\beta$-scale structure and develop- 
ment processes. J. Meteor. Soc. Japan, 82, 4565.

Nagata, M. and Y. Ogura, 1991: A modeling case study of interaction between heavy precipitation and a low-level jet over Japan in the Baiu season. Mon. Wea. Rev., 119, 1309-1336.

Ninomiya, K., 1984: Characteristics of Baiu front as a predominant subtropical front in the summer northern hemisphere. J. Meteor. Soc. Japan, 62, 880-894.

and T. Akiyama, 1992: Multi-scale features of Baiu, the Summer Monsoon over Japan and East Asia. J. Meteor. Soc. Japan, 70, 467-495.

Saito, K., T. Kato, H. Eito and C. Muroi, 2001: Documentation of the meteorological research institute/numerical prediction division unified nonhydrostatic model. Tech. Rep. Meteorological Research Institute, 42, 133pp.

Segami, A., K. Kurihara, H. Nakamura, M. Ueno, I. Takano and Y. Tatsumi, 1989: Operational mesoscale weather prediction with Japan Spectral Model. J. Meteor. Soc. Japan, 67, 907-923.

Shimizu, S., 1996: Studies on the meso- $\beta$ scale structures and features of precipitation in the Baiu frontal zone. Doctoral dissertation, Hokkaido University.

Yoshizaki, M., H. Seko and T. Kato, 2000: A report on a special observation of Baiu front over East China Sea and Kyushu in 1999 X-BAIU-99. Tenki, 47, 217-224 (in Japanese). 